\title{
Transposable elements continuously remodel the regulatory landscape, transcriptome, and function of decidual stromal cells
}

\author{
Katelyn Mika ${ }^{1,2}$ and Vincent J. Lynch ${ }^{3,}$
}

${ }^{1}$ Department of Human Genetics, The University of Chicago, 920 East 58th Street, CLSC 319C, Chicago, IL 60637, USA.

${ }^{2}$ Current address: Department of Organismal Biology and Anatomy, University of Chicago, 1025 E $57^{\text {th }}$ Street, Chicago, IL, 60637, USA

${ }^{3}$ Department of Biological Sciences, University at Buffalo, SUNY, 551 Cooke Hall, Buffalo, NY, 14260, USA.

‘Correspondence: vjlynch@buffalo.edu 


\begin{abstract}
Gene expression evolution underlies the origin, divergence, and conservation of biological characters including cell-types, tissues, and organ systems. Previously we showed that largescale gene expression changes in decidual stromal cells contributed to the origins of pregnancy in eutherians and the divergence of pregnancy traits in primates (Marinić et al., 2021; Mika et al., 2021a, 2021b), and that transposable elements likely contributed to these gene expression changes (Mika et al., 2021a). Here we show that two large waves of TEs remodeled the transcriptome and regulatory landscape of decidual stromal cells, including a major wave in primates. Genes nearby TE-derived regulatory elements are among the most progesterone responsive in the genome and play essential roles in orchestrating progesterone responsiveness and the core function of decidual cells by donating progesterone receptor binding sites to the genome. We tested the regulatory abilities of 89 TE consensus sequences and found nearly all acted as repressors in mammalian cells but that treatment with histone deacetylase inhibitors unmasked latent enhancer functions. These data indicate TEs have played an important role in the development, evolution, and function of primate decidual stromal cells and suggest a two-step model in which latent enhancer functions of TEs are unmasked after they lose primary repressors functions.
\end{abstract}

\title{
Introduction
}

Changes in gene regulatory evolution underlies the origin, divergence, and homology of cell-types, tissues, and organs. Thus, understanding the mechanisms of gene regulatory evolution is essential for understanding how anatomical systems evolve. One hypothesis of gene regulatory evolution proposes that genes gain and lose expression domains through a multi-step accumulation of small-scale mutations, such as point mutations or indels, that either create new or destroy old transcription factor binding sites (Stone and Wray, 2001). At the other extreme, a gene may evolve a regulatory element in a single step through the integration and cooption of a transposable element (TE) that harbors functional transcription factor binding sites (Bourque et al., 2008; El-Deiry et al., 1992; Jordan et al., 2003; Kunarso et al., 2010; Lynch et al., 2015; Polak and Domany, 2006; Wang et al., 2007). While there is ample data to support both models of gene regulatory evolution (reviewed in (Feschotte, 2008; Wray, 2007)), important questions with both models remain (Bourque et al., 2018). For example: Do TEs integrate with regulatory abilities, or as 'pre-regulatory elements' that need additional mutations to acquire regulatory functions? Do the functions of TE derived regulatory elements change, or is their evolution constrained by their 
functions upon integration? And does cooption of TEs into regulatory elements occur continuously or in a single wave? Answers to these (and other) questions are essential for understanding the contribution of TEs to gene regulatory evolution.

Extant mammals span several major evolutionary transitions during the origins, divergence, and conservation of pregnancy, including the origin a new cell-types in the uterine lining (endometrium), endometrial stromal fibroblasts (ESF) and decidual stromal cells (DSC) (Chavan et al., 2021; Erkenbrack et al., 2018; Wu et al., 2020), which mediate many of the maternal responses to pregnancy. For example, an essential step in the establishment and maintenance of pregnancy is the differentiation (decidualization) of ESFs into DSCs in response to progesterone acting through the progesterone receptor (PGR), the second messenger cyclic AMP (cAMP) acting through protein kinase A (PKA) and the transcription factor FOXO1 (Gellersen and Brosens, 2003; Kajihara et al., 2013), and, in some species, to fetal signals (Gellersen et al., 2007). Decidualization evolved in the stem lineage of Eutherian mammals (Kin et al., 2015, 2014; Mess and Carter, 2006) and induces large-scale gene regulatory, cellular, and physiological changes in the endometrium that are essential for successful implantation and pregnancy in many eutherians including humans.

We have previously shown that hundreds of genes gained and lost endometrial expression coincident with the origins of pregnancy and decidualization in early mammals (Lynch et al., 2015; Marinić et al., 2021), and that a second major episode of gene expression evolution occurred in primates (Mika et al., 2021a, 2021b). This latter wave of gene expression evolution occurred coincident with the origin of numerous primate-specific female reproductive and pregnancy traits including menstruation (Burley, 1979; Emera et al., 2012; Finn, 1998; Strassmann, 1996), decidualization in the absence of fetal signals (spontaneous decidualization) (Carter and Mess, 2017; Gellersen et al., 2007; Gellersen and Brosens, 2003; Kin et al., 2016, 2015; Mess and Carter, 2006), deeply invasive placentas (Carter et al., 2015; Pijnenborg et al., 2011a, 2011b; Soares et al., 2018), and a derived parturition signal (Csapo, 1956; Csapo and Pinto-Dantas, 1965). Remarkably, TEs appear to have played an important role in the origins of pregnancy through cooption into progesterone-responsive cis-regulatory elements in DSCs (Lynch et al., 2015; Mika et al., 2021a) and may have played a similar role during the evolution of primatespecific pregnancy traits (Lynch et al., 2015; Mika et al., 2021a). Here we show that successive waves of TEs have been coopted into progesterone-responsive cis-regulatory elements, including 
a rolling wave of TE cooption in primates. Genes with regulatory elements derived from primatespecific TEs are among the most strongly differentially regulated by progesterone, have essential roles in decidualization, and likely contribute to primate-specific pregnancy traits such as spontaneous decidualization. Finally, we tested 89 consensus TE sequences, as a proxy for ancestral TE sequences, and found that nearly all have dominant repressor functions and latent enhancer functions in mammalian cells. These data suggest that primate-specific TEs played an important role in gene regulatory evolution in primate DSCs. Furthermore, our data suggest a general two-stage model of TE domestication into gene regulatory elements, whereby loss of ancestral repressor functions unmasks hidden enhancer functions.

\section{Results}

\section{Transposable elements are major contributors to regulatory elements in DSCs}

We have previously shown that Mammalian-, Therian-, and Eutherian-specific TEs played an important role in the origin of new cis-regulatory elements in DSCs during the evolution of pregnancy (Lynch et al., 2015)) and are enriched nearby genes that gained and lost expression in primate DSCs (Lynch et al., 2015; Mika et al., 2021a). Here we expanded these studies to all classes and ages of TEs using previously generated H3K4me3 ChIP-Seq, H3K27ac ChIP-Seq, FAIRE-Seq and DNasel-Seq data to identify promoters, enhancers, and regions of open chromatin (Lynch et al., 2015; Mika et al., 2021a). We found that 58.7\% of H3K27ac and 53.0\% of H3K4me3 ChIP-Seq peaks, $42.2 \%$ of FAIRE-Seq peaks, and $67.2 \%$ of DNasel-Seq peaks overlapped annotated transposable elements (Figure 1A). Next, we annotated these TEs by their lineage specificity and found that TEs from different age classes differentially contributed to each kind of regulatory element: relatively young (i.e., Primate-specific) TEs dominated the DNasel, H3K27ac, and H3K4me3 datasets, whereas relatively ancient TEs (i.e., Eutherian-specific and older) were more common in the FAIRE dataset (Figure 1B). 427 TE families were enriched (eTE; $>1.5$-fold, $P \leq 0.05$, binomial test) within H3K27ac and H3K4me3 ChIP-Seq, and FAIRE-, DNase Seq peaks (Figure 1C), most of which were Eutherian- and Primate-specific (Figure 1D).

\section{TE-derived regulatory elements are enriched in transcription factor binding sites that regulates DSCs}

To determine if TEs donated motifs for specific transcription factors, we identified overrepresented transcription factor binding sites (TFBS) within eTE-derived regions of FAIRE-seq, DNase-seq, H3K27ac ChIP-Seq and H3K4me3 ChIP-Seq peaks using previously published 
ENCODE ChIP-Seq data for 132 transcription factors as well as previously published PGR ChIP. Seq data generated from from human DSCs (Mazur et al., 2015). 53 TFBSs were enriched within regulatory eTEs relative to genomic TFBS abundances (FDR=0.05; Figure 2A), most notably PGR (enrichment=10.31, FDR $<1.00 \times 10^{-250}$ ), AHR (enrichment=2.00, FDR=1.00×10-5), and GATA (enrichment=1.25, FDR=1.30×10-20). We also observed enrichment for the KRAB-ZFPs ZNF263

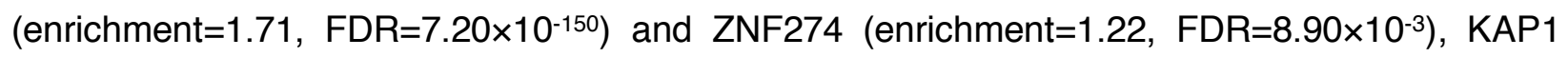
(also known as TRIM18; enrichment=2.00, FDR=7.20 $\times 10^{-41}$ ), which binds KRAB-ZFPs and functions as a scaffold for the recruitment of histone modifying co-repressor complexes, and parts of the SWI/SNF chromatin remodeling complex such as BAF155 (enrichment=2.36,

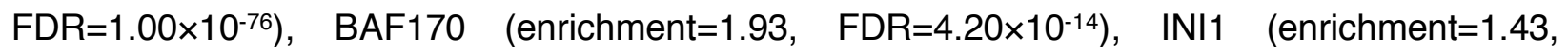
FDR $=9.10 \times 10^{-18}$ ), and BRG1 (enrichment=1.38, FDR=2.70 $\times 10^{-5}$ ). These data suggest that TEs have donated binding sites for transcription factors that mediate decidualization such as PGR and its obligate co-factor GATA2 (Rubel et al., 2016, 2011), as well as general transcriptional repressors and chromatin modifying proteins (Figure 2B).

\section{TE-derived regulatory elements augment ancient progesterone responsiveness}

Our observation that specific TE families are enriched in DSC regulatory elements suggests that they may contribute to gene expression changes that occur during progesteroneinduced decidualization and changes in decidualization-induced gene expression during human evolution. To test this hypothesis, we used parsimony to reconstruct the evolutionary history of gene expression in the pregnant uterus (Figure 3A) (Marinić et al., 2021), RNA-Seq data from human ESFs and DSCs to quantify gene expression changes induced by decidualization (Figure 3B), and previously published promoter capture $\mathrm{HiC}(\mathrm{pcHiC})$ data generated from human DSCs (Sakabe et al., 2020) to associate genes with putative regulatory elements (Figure 3C). We found that genes with eTE-derived regulatory elements were generally more strongly differentially regulated by decidualization than genes without eTE-derived regulatory elements, especially genes that were more recently recruited into endometrial expression (Figure 3D).

\section{TE-derived regulatory elements are enriched in PGR binding sites}

Our observations that TEs are enriched in PGR binding sites and are associated with genes that are strongly differentially expressed upon decidualization prompted us to explore the contribution of TEs to PGR binding sites in greater detail. We found that $62.8 \%(5344 / 8510)$ of 
PGR ChIP-Seq peaks in DSCs contained TEs (Figure 4A), nearly all of which are Mammalian-, Eutherian-, and Primate-specific (Figure 4B). PGR ChIP-Seq peaks, however, are almost exclusively enriched ( $>1.5$-fold, $P \leq 0.05$, binomial test) in Eutherian- and Primate-specific TEs (Figure 4C). Consistent with a functional role for TE-derived PGR binding sites in orchestrating progesterone responsiveness, genes associated with TE-derived PGR binding sites by pcHiC (Figure 4D) were more strongly differentially expressed during decidualization than genes not associated with TE-derived PGR binding sites (Figure 4E); This trend was more pronounced for recently recruited genes (Figure $4 \mathrm{E}$ ). We also found that genes associated by pcHiC with TEderived PGR binding sites were significantly more dysregulated by siRNA-mediated PGR knockdown in DSCs (Figure 4F) than genes not associated with TE-derived PGR binding sites (Figure 4G).

\section{TE-derived PGR binding sites in primates regulate genes essential for decidualization}

To explore the functional consequences of eTE-derived PGR binding sites, we first binned eTEs into ancient mammalian or primate-specific categories based on our observation that TEs in regulatory elements are predominantly from two age classes. Next, we used the pcHiC data to associate genes with category of eTE-derived PGR binding site and tested whether these genes were enriched in biology pathways (KEGG, Panther, Wikipathway, Reactome) using the overrepresentation analyses implemented in WebGestalt (Liao et al., 2019). Of the 965 genes associated with eTE-derived PGR binding sites expressed in DSCs (TPM $\geq 2$ ), 631 were associated with primate-specific eTE-derived PGR binding sites. These genes were enriched in 113 pathways at FDR $\leq 0.10$. Among the enriched pathways were many that play important roles in decidualization and pregnancy (Table 1), such as Wnt, FoxO, and prolactin signaling, and various pathways related to regulation of the cell cycle which plays a critical role in the earliest stages of decidualization (Table 2). In contrast, the 334 genes only associated with ancient mammalian eTE-derived PGR binding sites were not enriched in any pathway at at FDR $\leq 0.10$.

\section{Consensus TEs are repressors with latent enhancer potential}

It is not clear if TEs integrate with regulatory abilities, and therefore immediately function as regulatory elements, or if they integrate as 'pre-regulatory elements' that are weakly- or nonfunctional and require additional mutations to acquire regulatory functions. To test these scenarios, we selected 89 enriched TEs, synthesized their consensus sequences (conTE), and 
cloned them into the pGL3-Basic[minP] luciferase reporter vector. Next, we transiently transfected human ESFs and DSCs with each conTE reporter and used a dual luciferase reporter assay to test their regulatory abilities. We found that 55 (62\%) the conTE reporters functioned as repressors in ESFs while 58 (65\%) functioned as repressors in DSC (FDR $\leq 0.05)$, in contrast only $13(3 \%)$ and 21 (23\%) had enhancer functions in ESFs and DSCs (Figure 5A; FDR $\leq 0.05)$. To test whether these effects were cell-type specific, we repeated the luciferase reporter assay in the human hepatocellular carcinoma cell line HepG2 and again observed that 59/89 (66\%) were strong repressors (FDR $\leq 0.05$ ) whereas 28 were enhancers (Figure 5A; FDR $\leq 0.05$ ). To determine if these results were species specific we repeated the luciferase assay in mouse embryonic fibroblasts (MEFs) and observed that 51 (57\%; FDR $\leq 0.05)$ of conTEs were repressors (34 were enhancers; FDR $\leq 0.05$ ) whereas in elephant dermal fibroblasts 21 (24\%; FDR $\leq 0.05$ ) were repressors (34 were enhancers; FDR $\leq 0.05$ ) (Figure $\mathbf{5 A}$ ). While some conTEs, such as LTR elements, which have strong internal promoters, had enhancer functions in all cell-types, significantly more were repressors than expected by chance in ESFs (Binomial $P=0.027$ ), DSCs (Binomial $P=1.00 \times 10^{-6}$ ), HepG2 (Binomial $P<1.00 \times 10^{-6}$ ), and MEFs (Binomial $P=0.027$ ).

Our observation that TEs enriched within regulatory elements and open chromatin are also enriched in binding sites for KRAB-ZFPs, KAP1, as well as histone modifying co-repressor complexes, suggest that conTEs may function as repressors because they are recognized by the host cell anti-TE machinery and silenced (Feschotte and Gilbert, 2012; Matsui et al., 2010; Rowe et al., 2010). To test this hypothesis, we repeated the luciferase reporter assay in ESFs and DSCs and treated cells with the mammalian class I and II histone deacetylase (HDAC) inhibitor trichostatin A (TSA). TSA treatment de-repressed 30/35 (86\%; FDR $\leq 0.05$ ) and 39/55 (71\%; FDR $\leq 0.05$ ) of the conTEs that were repressors in untreated ESFs and DSCs, respectively (Figure 5B). TSA treatment also unmasked the latent enhancer functions of 29 conTEs in ESFs and 26 conTEs in DSCs (for example: MIR3, MIRb, and MIRc, MamRep1879, and MER96b). Thus, while the majority of conTEs repress luciferase expression, their repressive abilities are likely HDAC dependent.

The preponderance of repressor functions among conTEs and their dependence on HDACs suggests that conTEs may be recognized by the KRAB-ZFPs/KAP1 TE suppression system and silenced by histone modifying co-repressor complexes (NuRD, CoREST, SWI/SNF) (Feschotte and Gilbert, 2012; Imbeault et al., 2017; Matsui et al., 2010; Rowe et al., 2010). To test this 
hypothesis, we repeated the luciferase reporter assay in KAP1 knockout mouse embryonic fibroblasts (MEF KAP1-/), but again observed 53 conTEs (59\%; FDR $\leq 0.05$ ) were repressors and relief of repression for only $8(9 \%$; FDR $\leq 0.05)$ conTEs (Figure 5A). To infer if repression may be mediated by KRAB-ZFPs, we took advantage of their restricted lineage specificity and tested the regulatory abilities of conTEs in chicken embryonic fibroblasts; The chicken genome only encodes 41 KRAB-ZFP, none of which are expressed in chicken embryonic fibroblasts (Addison et al., 2015). In stark contrast to the different mammalian cell-types we tested, only 18 (20\%; FDR $\leq 0.05)$ of the conTEs functioned as repressors whereas $69(78 \%$; FDR $\leq 0.05)$ were strong enhancers in CEFs (Figure 5A).

Finally, we used multidimensional scaling to explore whether conTEs could be grouped into distinct clusters based on their regulatory abilities in different cell-types. We found that conTEs formed four clusters in the MDS plot, corresponding to those with weak, moderate, and strong enhancer functions and those with repressor functions (Figure 5C). Similarly, hierarchical clustering grouped conTEs with enhancer and repressor functions (Figure $\mathbf{5}$ - figure supplement 1). Consistent with our observation that the regulatory functions of conTEs were similar in different mammalian cell-types but different in CEFs, CEFs did not cluster with mammalian cell-types in an MDS plot (Figure $\mathbf{5}$ - figure supplement 2). Collectively these data indicate that while a few conTEs, mostly LTRs, have strong enhancer or promoter abilities, most conTEs function as HDAC-dependent repressors in mammalian cells.

\section{Discussion}

Two waves of transposable element cooption remodel the transcriptome and regulatory landscape of decidual stromal cells

Transposable elements are so frequently coopted into regulatory elements that it is not possible to cite all or even most studies reporting either the cooption of individual TEs or largescale cooption of (almost) entire TE families. Previous studies, for example, have dissected in great detail the cis-regulatory element that drives extra-pituitary prolactin $(P R L)$ in human decidual stromal cells (DSCs), which is normally expressed by the pituitary and immune cell-types (Gerlo et al., 2006). These studies found that human $P R L$ expression is initiated from an alternative promoter located $5.8 \mathrm{~kb}$ upstream of the canonical pituitary transcription start site which contains binding sites for transcription factors that are essential for the identity and function of DSCs including PGR, FOXO1A, ETS1, CEBPB, and FOS (Gerlo et al., 2006). Remarkably, the human 
decidual $P R L$ promoter is derived from a primate-specific long terminal repeat (LTR)-like transposable element in the medium reiterated repeat (MER39) family and an upstream enhancer derived from a Eutherian-specific MER1 class of DNA transposon (MER20) (Gerlo et al., 2006). However, while there is little evidence that other MER39 elements function as promoters (Emera and Wagner, 2012), MER20 elements function as enhancers in DSCs for numerous genes across the genome (Lynch et al., 2011).

These data suggest that Eutherian-specific transposable elements played a role in re-wiring the gene regulatory network during evolution of pregnancy and decidualization. Consistent with this observation, we previously found large-scale cooption of Mammalian-, Therian-, and Eutherian-specific TEs (AncMamTEs) into progesterone responsive cis-regulatory elements. Here we expanded on these studies and found that 427 TE families were enriched in DSC regulatory elements, nearly half of which were primate-specific. Thus, there were at least two waves of TE cooption into decidual regulatory elements - a first wave in early mammals and a second wave in primates. Remarkably, genes associated by $\mathrm{pcHiC}$ with TE-derived regulatory elements were significantly more responsive to progesterone than genes without TE derived cisregulatory elements. Furthermore, genes with primate-specific TE-derived PGR binding sites were more progesterone responsive than genes with either ancient TE-derived PGR binding sites or genes without TE-derived PGR binding sites. These data suggest that TEs may have played a role in rewiring the progesterone responsive gene regulatory network both during the evolution of pregnancy in early mammals and in primates.

\section{Primate-specific transposable elements contribute to the function of decidual stromal cells}

While eutherian mammals share a suite of traits mediated by endometrial stromal lineage cells that support prolonged pregnancies, there is also considerable variation in pregnancy traits within eutherians. Catarrhine primates, for example, have evolved spontaneous decidualization (differentiation) of endometrial stromal fibroblasts (ESFs) into decidual stromal cells (DSCs) under the combined action of progesterone, cyclic adenosine monophosphate (cAMP), and other unknown maternal signals (Carter and Mess, 2017; Gellersen et al., 2007; Gellersen and Brosens, 2003; Kin et al., 2016, 2015; Mess and Carter, 2006). Decidualization induces dramatic gene expression and functional changes (Aghajanova et al., 2011; Gellersen et al., 2007; Giudice, 2003), but the molecular mechanisms that underlie the evolution of spontaneous decidualization are largely unknown. We found that coopted primate-specific TEs regulate genes in several 
pathways that involved in decidualization and the cell cycle (Table 1 and Table 2), most notably the FOXO1 signaling pathway. For example, the transcription factor FOXO1 plays a particularly important function as a key regulator of decidualization, which integrates cAMP and progesterone signaling through physical and functional interactions with the progesterone receptor and other transcription factors to direct expression of progesterone response genes (Gellersen and Brosens, 2003; Lynch et al., 2009; Takano et al., 2007). Similarly, among the earliest steps in the decidualization process is cell cycle exit (Das, 2009; Logan et al., 2010); progesterone initially induces cell cycle arrest at the G0/G1 checkpoint followed by arrest at the G2/M checkpoint both of which are regulated by p53 signaling (Logan et al., 2012). These data suggest that primatespecific TEs may have played a role in the origin of spontaneous decidualization by altering the regulation of genes in the FOXO1 signaling and cell cycle regulation pathways.

\section{A multi-stage model for transposable element domestication}

Numerous studies have shown that transposable elements have donated binding sites for transcription factors to the genome, can be bound by transcription factors, and have been coopted into cis-regulatory elements (El-Deiry et al., 1992; Jordan et al., 2003; Kunarso et al., 2010; Lynch et al., 2011; Polak and Domany, 2006; Wang et al., 2007), but it generally has not been determined if TEs integrate into the genome with regulatory functions and therefore immediately function as regulatory elements or if they integrate as 'pre-regulatory elements' that are not immediately functional and require additional mutations to acquire regulatory functions. We addressed this question using luciferase assay functional tests of conTEs and found the majority of consensus TEs have enhancer ability but this ability is silenced in mammalian cells, perhaps by KRAB-ZFPs and the NURD HDAC inhibitory complex. We do see a mild enrichment within the dataset of TEs with regulatory marks in DSCs. This enrichment is likely low because 1) the elements analyzed have likely escaped repression by KRAB-ZFPs in order to be coopted into enhancers, and 2) the datasets used to identify KRAB-ZFP, KAP1, and the majority of other transcription factors, were from ENCODE and not DSCs. However, the relief of repression seen in chicken cells, which do not express KRAB-ZFPs (Addison et al., 2015), is at least coincidental evidence that KRAB-ZFPs may play a role in silencing conTEs. In embryonic stem cells, KAP1 binds the KRAB-ZFPs and coordinates the silencing of the bound TE (Feschotte and Gilbert, 2012; Matsui et al., 2010; Rowe et al., 2010). However, in adult somatic tissues the role of KAP1 is unclear (Ecco et al., 2016; Matsui et al., 2010; Rowe et al., 2010). Here, silencing of the conTEs in MEFs appears to be KAP1 independent. These results need to be confirmed, for example, by 
ChIP to demonstrate conTEs are indeed bound by KRAB-ZFPs. We hypothesize that only when TEs escape this silencing regulation are they coopted by the genome to play a regulatory role.

\section{Caveats and limitations}

Ideally, we would use an ancestral sequence reconstruction (ASR) of each TE to determine if TEs had ancestral regulatory abilities. However, reconstructing the earliest ancestral sequence for most TEs is not possible because most TEs do not have an outgroup to root their phylogeny and therefore we cannot identify which node is the deepest ancestor. In place of an ASR, we and others who have explored similar questions used conTEs. This introduces an obvious limitation to our inferences: the conTE may not be an accurate representation of the deepest ancestral sequence. Indeed, there is no guarantee that a consensus sequence represents a sequence that ever existed. Another possible limitation of our approach is the use of immortalized ESFs maintained under standard tissue conditions for both functional genomic studies and luciferase assays, which may not faithfully represent in vivo functions. These limitations impact virtually every study of primate pregnancy, however, endometrial organoids and iPSC-derived endometrial stromal fibroblasts are promising systems in which to study the evolution of pregnancy (Abbas et al., 2020; Boretto et al., 2017; Marinić et al., 2020; Rawlings et al., 2021; Turco et al., 2017). Finally, our reporter assays used an episomal vector rather than a construct inserted into the genome which may bias our results by removing context dependent effects of regulatory elements within the genome.

\section{Conclusions}

Here we demonstrate that there were two major waves of TE cooption into regulatory elements in endometrial stromal lineage cells, specifically in ancient mammals and primates, and that these TEs donated functional transcription factor binding sites to the genome. Furthermore, the majority of the TEs tested have context-dependent repressor and enhancer functions, suggesting they may have integrated into the genome with regulatory abilities and that their genomic functions are cell-type dependent. Genes regulated by TE-derived regulatory elements are among the most progesterone responsive in the genome and are associated with essential functions of stromal cells and the processes of decidualization. These data suggest that TEs have played an important role in the evolution of gene regulation and function of endometrial stromal lineage cells. This may have had a particularly significant effect in primates, which have divergent pregnancy traits than other mammals. 


\section{Materials and Methods}

\section{Identification of TE containing regulatory elements}

We used previously published ChIP-Seq data generated from human DSCs that were downloaded from NCBI SRA and processed remotely using Galaxy (Afgan et al., 2016). ChIPSeq reads were mapped to the human genome (GRCh37/hg19) using HISAT2 (Kim et al., 2019, 2015; Pertea et al., 2016) with default parameters and peaks called with MACS2 (Feng et al., 2012; Zhang et al., 2008) with default parameters. Samples included H3K4me3 (GSE61793), H3K27ac (GSE61793), PGR (GSE69539), the PGR A and B isoforms (GSE62475), and DNase1Seq (GSE61793). FAIRE-Seq peaks were downloaded from the UCSC genome browser and not re-called.

To identify regulatory elements derived from transposable elements (TEs), peaks were intersected with the RepMask 3.2.7 track at the UCSC genome browser (repbase libraries release 20050112). Non-transposable element annotations were removed and corrected for fragmented annotations. To identify TEs that were significantly enriched within TE-derived peaks the TEanalysis pipeline (https://github.com/4ureliek/TEanalysis) was used with 10,000 replicates. A custom bioinformatic pipeline was used to determine enrichment of transcription factor binding sites in TEs that intersect with the DSC FAIRE-seq, DNase-seq, H3K27ac ChIP-Seq, and H3K4me3, and PGR ChIP-Seq peaks (https://github.com/4ureliek/TEanalysis) (Lynch et al., 2015) versus the genomic abundance of ChIP-Seq peaks; 10,000 bootstrap reshufflings were used to assess statistical significance. Scripts are publicly available and archived at https://github.com/4ureliek/TEanalysis. The location of ChIP-Seq peaks in hg19 ENCODE data was downloaded from the USCS genome browser (Txn Fac ChIP V2 - Transcription Factor ChIPSeq from ENCODE (V2)). The location of PGR ChIP-Seq peaks was obtained from GEO (GSE94036) and is available (Mazur et al., 2015). We also used previously published promoter capture $\mathrm{HiC}$ (pcHiC) generated from DSCs (Sakabe et al., 2020) to associate genes with regulatory elements (SDY1626).

We also used previously published RNA-Seq gene expression data generated from human primary human ESFs treated for $48 \mathrm{hr}$ with control non-targeting and PGR-targeting siRNA prior to decidualization stimulus for $72 \mathrm{hr}$. Data were downloaded from NCBI SRA and processed remotely using the Galaxy platform (https://usegalaxy.org/; Version 20.01). RNA-Seq datasets were transferred from SRA to Galaxy using the Download and Extract Reads in FASTA/Q format 
from NCBI SRA tool (version 2.10.4+galaxy1). We used HISAT2 (version 2.1.0+galaxy5) to align reads to the Human hg38 reference genome using single- or paired-end options depending on the dataset and unstranded reads, and report alignments tailored for transcript assemblers including StringTie. Transcripts were assembled and quantified using StringTie (v1.3.6) (Pertea et al., 2016, 2015), with reference file to guide assembly and the "reference transcripts only" option, and output count files for differential expression with DESeq2/edgeR/limma-voom. Differentially expressed genes were identified using DESeq2 (Love et al., 2014) (version 2.11.40.6+galaxy1). The reference file for StringTie guided assembly was wgEncodeGencodeBasicV33.

\section{Gene expression data and parsimony reconstruction of gene expression gain/loss}

We used previously generated RNA-Seq data from the pregnant or gravid uterus of amniotes (Supplementary Table 1) and Kallisto version 0.42.4 (Bray et al., 2016) to quantify gene expression levels. Kallisto was run with default parameters, bias correction, 100 bootstrap replicates. Kallisto outputs are gene expression levels in transcripts per million (TPM). Our previous studies of endometrial gene expression data suggests that genes with a TPM $\leq 2$ are likely from transcriptionally suppressed genes (Wagner et al., 2013). This threshold is consistent with one obtained by comparing the transcript abundance with the chromatin state of the respective gene (Hebenstreit et al., 2011) and classified genes with TPM $\geq 2$ as expressed and those with TPM $<2$ as not expressed. Next, we used Mesquite (v2.75) and parsimony optimization to reconstruct ancestral gene expression states, and identified genes that gained and lost endometrial expression in Amniotes. Expression was classified as an unambiguous gain if a gene was not inferred as expressed at the ancestral node (state 0) but inferred as expressed in a descendent node (state 1) and vice versa for the classification of a loss from endometrial expression.

\section{Over Representation Analyses (ORA)}

We used WebGestalt v. 2019 (Liao et al., 2019) to identify enriched ontology terms using overrepresentation analysis (ORA). We used ORA to identify enriched terms for three pathway databases (KEGG, Reactome, and Wikipathway), three disease databases (Disgenet, OMIM, and GLAD4U), and a custom database of genes implicated in preterm birth by GWAS. The preterm birth gene set was assembled from the NHGRI-EBI Catalog of published genome-wide association studies (GWAS Catalog), including genes implicated in GWAS with either the 
ontology terms "Preterm Birth" (EFO_0003917) or "Spontaneous Preterm Birth" (EFO_0006917), as well as two recent preterm birth GWAS (Sakabe et al., 2020; Warrington et al., 2019) using a genome-wide significant P-value of 9x10-6. The custom gmt file used to test for enrichment of preterm birth associated genes is included as a supplementary data file to Figure 2 (Figure 2 Source data 1).

\section{Transposable element reporter vectors}

To generate luciferase reporter vectors for functional testing, we selected 79 of the 427 TE families enriched within DSC regulatory regions as marked H3K4me3 ChIP-seq, H3K27ac ChIP-seq, DNasel-seq, and FAIRE-Seq datasets. These 79 TEs also met the following criteria: 1) At least 1 element from every lineage; and 2) Represented all 4 classes of TEs (LTR, LINE, SINE, and DNA). Consensus sequences for these elements were taken from the database Dfam (Wheeler et al., 2013). 10 additional TEs also found in the enriched 427 were then chosen that were unique to Old World Monkeys or younger and their consensus sequences were also obtained from Dfam (Wheeler et al., 2013). The total set of elements were biased towards, but not limited to, the DNA class of transposable elements. These 89 consensus sequences were then synthesized by Genscript and cloned into the pGL3 Basic vector (Promega) with an added minimal promoter (pGL3Basic[minP]) and are available in the supplementary materials.

\section{Cell lines}

Human hTERT-immortalized endometrial stromal fibroblasts were purchased from ATCC (CRL-4003), their identity has been authenticated by ATCC and were determined by the Lynch lab to be mycoplasma free. KAP1 knockout mouse embryonic fibroblasts (MEFs) and Flox/Flox control MEFs were gift from D. Trono (Ecole Polytechnique Fédérale de Lausanne), their identity has been authenticated by the Trono lab and were determined by the Lynch lab to be mycoplasma free. Chicken embryonic fibroblast cells were purchased from ATCC (CRL-12203), their identity has been authenticated by ATCC and were determined by the Lynch lab to be mycoplasma free. HEPG2 cells were a gift from C. Brown (University of Pennsylvania), their identity has been authenticated by the Brown lab and were determined by the Lynch lab to be mycoplasma free. African elephant fibroblasts were a gift from the San Diego Frozen Zoo, their identity has been authenticated by the San Diego Frozen Zoo and were determined by the Lynch lab to be mycoplasma free. 


\section{Cell culture and luciferase assays}

Endometrial stromal fibroblasts, KAP1 knockout mouse embryonic fibroblasts (MEFs), and Flox/Flox control MEFs were maintained in phenol red free DMEM (Gibco) supplemented with 10\% charcoal stripped fetal bovine serum (CSFBS; Gibco), 1x ITS (Gibco), 1\% sodium pyruvate (Gibco), and 1\% L-glutamine (Gibco). Chicken embryonic fibroblast cells (ATCC CRL12203) and HEPG2 cells were maintained in phenol red containing DMEM + Glutamax (Gibco) supplemented with 10\% fetal bovine serum (FBS, Gibco) and Normocin (InviviGen). Elephant fibroblasts were maintained in 1:1 MEM (Corning cellgro) supplemented with 10\% FBS, 1\% penstrep (Gibco), 1x sodium pyruvate (Gibco), and 1x L-glutamine (Gibco) to FGM-2 (Lonza), made per manufacturer's instructions.

Confluent cells in 96 well plates in $80 \mu$ l of Opti-MEM (Gibco) were transfected with 100ng of the TE containing luciferase plasmid and 10ng of the $\mathrm{pRL}$-null renilla vector (Promega) with $0.1 \mu \mathrm{l}$ PLUS reagent (Invitrogen) and $0.25 \mu \mathrm{l}$ of Lipofectamine LTX (Invitrogen) in 20 $\mu$ l Opti-MEM. The cells incubated in the transfection mixture for 6hrs and the media was replaced with the maintenance media overnight. Decidualization of ESFs was then induced by incubating the cells in the decidualization media: DMEM with phenol red (Gibco), 2\% CSFBS (Gibco), 1\% sodium pyruvate (Gibco), 0.5mM 8-Br-cAMP (Sigma), and $1 \mu \mathrm{M}$ of the progesterone analog medroxyprogesterone acetate (Sigma) for 48hrs. ESFs (decidualization controls) were incubated in the decidualization control media (phenol red free DMEM (Gibco), 2\% CSFBS (Gibco), and 1\% sodium pyruvate (Gibco) instead for $48 \mathrm{hrs}$. For trichostatin A (TSA; Tocris Bioscience) trials, $1 \mu \mathrm{M}$ TSA was added to all the medias from plating through decidualization. After decidualization for ESFs and DSCs or after 48hrs from transfection for other cell types, Dual Luciferase Reporter Assays (Promega) were started by incubating the cells for 15 mins in $20 \mu$ l of $1 \mathrm{x}$ passive lysis buffer. Luciferase and renilla activity were then measured using the Glomax multi+ detection system (Promega). Luciferase activity values were standardized by the renilla activity values and background activity values as determined by measuring luminescence from the pGL3Basic[minP] plasmid with no insert. Each luciferase experiment was replicated in 4-6 independent experiments. To identify significant expression shifts, we performed Wilcoxon tests on the data, and adjusted by the Benjamini and Hochberg (Benjamini and Hochberg, 1995) method for multiple testing; significance was determined by having an adjusted $p$-value $\leq 0.05$. 


\section{Data exploration and Multi-Dimensional Scaling (MDS)}

We used classical Multi-Dimensional Scaling (MDS) to explore the structure of luciferase assay data. MDS is a multivariate data analysis method that can be used to visualize the similarity/dissimilarity between samples by plotting data points onto two-dimensional plots. MDS returns an optimal solution that represents the data in a two-dimensional space, with the number of dimensions $(\mathrm{k})$ specified a priori. Classical MDS preserves the original distance metric, between data points, as well as possible. MDS was performed using the vegan $\mathrm{R}$ package (Oksanen et al., 2019) with four reduced dimensions. Luciferase assay data were grouped using K-means clustering with $\mathrm{K}=2-6, \mathrm{~K}=4$ optimized the number of distinct clusters and cluster memberships.

\section{Author Contributions}

KM and VJL collaboratively conceived, designed, interpreted data, and wrote this paper, as well as analyzed the expression shifts of genes associated with TE derived regulators or TE derived PGR binding sites in response to progesterone signaling and did the binding site enrichment analyses. KM analyzed the RNA-Seq data, performed the gene expression calling, completed the parsimony reconstruction, and prepped, conducted, and analyzed the luciferase assays and associated cell culture. VJL identified the TE containing regulatory elements.

\section{Acknowledgements}

The authors thank Aurelie Kapusta for assistance with running the TE enrichment program, D. Trono (Ecole Polytechnique Fédérale de Lausanne) for providing the KAPKO and control MEFs, C. Brown (University of Pennsylvania) for providing the HEPG2 cells, and N. Sakabe (University at Chicago) for providing the pcHiC interaction data. This study was supported by a grant from the March of Dimes (March of Dimes Prematurity Research Center to principal investigator VJL) and a Burroughs Welcome Fund Preterm Birth Initiative grant (1013760, to principal investigator VJL). The funders had no role in study design, data collection and analysis, decision to publish, or preparation of the manuscript. 


\section{References}

Abbas Y, Brunel LG, Hollinshead MS, Fernando RC, Gardner L, Duncan I, Moffett A, Best S, Turco MY, Burton GJ, Cameron RE. 2020. Generation of a three-dimensional collagen scaffold-based model of the human endometrium. Interface Focus 10:20190079. doi:10.1098/rsfs.2019.0079

Addison JB, Koontz C, Fugett JH, Creighton CJ, Chen D, Farrugia MK, Padon RR, Voronkova MA, McLaughlin SL, Livengood RH, Lin C-C, Ruppert JM, Pugacheva EN, Ivanov AV. 2015. KAP1 Promotes Proliferation and Metastatic Progression of Breast Cancer Cells. Cancer Res 75:344-355. doi:10.1158/0008-5472.CAN-14-1561

Afgan E, Baker D, van den Beek M, Blankenberg D, Bouvier D, Čech M, Chilton J, Clements D, Coraor N, Eberhard C, Grüning B, Guerler A, Hillman-Jackson J, Von Kuster G, Rasche E, Soranzo N, Turaga N, Taylor J, Nekrutenko A, Goecks J. 2016. The Galaxy platform for accessible, reproducible and collaborative biomedical analyses: 2016 update. Nucleic Acids Res 44:W3-W10. doi:10.1093/nar/gkw343

Aghajanova L, Tatsumi K, Horcajadas JA, Zamah AM, Esteban FJ, Herndon CN, Conti M, Giudice LC. 2011. Unique transcriptome, pathways, and networks in the human endometrial fibroblast response to progesterone in endometriosis. Biol Reprod 84:801815. doi:10.1095/biolreprod.110.086181

Bao L, Tessier C, Prigent-Tessier A, Li F, Buzzio OL, Callegari EA, Horseman ND, Gibori G. 2007. Decidual prolactin silences the expression of genes detrimental to pregnancy. Endocrinology 148:2326-2334. doi:10.1210/en.2006-1643

Benjamini Y, Hochberg Y. 1995. Controlling the False Discovery Rate: A Practical and Powerful Approach to Multiple Testing. J R Stat Soc Ser B Methodol 57:289-300. doi:10.1111/j.2517-6161.1995.tb02031.x

Boretto M, Cox B, Noben M, Hendriks N, Fassbender A, Roose H, Amant F, Timmerman D, Tomassetti C, Vanhie A, Meuleman C, Ferrante M, Vankelecom H. 2017. Development of organoids from mouse and human endometrium showing endometrial epithelium physiology and long-term expandability. Development 144:1775-1786. doi:10.1242/dev.148478

Bourque G, Burns KH, Gehring M, Gorbunova V, Seluanov A, Hammell M, Imbeault M, Izsvák Z, Levin HL, Macfarlan TS, Mager DL, Feschotte C. 2018. Ten things you should know about transposable elements. Genome Biol 19:199. doi:10.1186/s13059-018-1577-z

Bourque G, Leong B, Vega VB, Chen X, Lee YL, Srinivasan KG, Chew J-L, Ruan Y, Wei C-L, 
$\mathrm{Ng} \mathrm{HH}$, Liu ET. 2008. Evolution of the mammalian transcription factor binding repertoire via transposable elements. Genome Res 18:1752-1762. doi:10.1101/gr.080663.108

Bray NL, Pimentel H, Melsted P, Pachter L. 2016. Near-optimal probabilistic RNA-seq quantification. Nat Biotechnol 34:525-527. doi:10.1038/nbt.3519

Burley N. 1979. The Evolution of Concealed Ovulation. Am Nat 114:835-858. doi:10.1086/283532

Carter AM, Mess AM. 2017. Placentation in the colugos Cynocephalus volans and Galeopterus variegatus (Dermoptera) and the transition from labyrinthine to villous placentation in primates. Placenta 55:47-53. doi:10.1016/j.placenta.2017.05.006

Carter EB, Bishop KC, Goetzinger KR, Tuuli MG, Cahill AG. 2015. The impact of chorionicity on maternal pregnancy outcomes. Am J Obstet Gynecol 213:390.e1-390.e7. doi:10.1016/j.ajog.2015.05.027

Chavan AR, Griffith OW, Stadtmauer DJ, Maziarz J, Pavlicev M, Fishman R, Koren L, Romero R, Wagner GP. 2021. Evolution of Embryo Implantation Was Enabled by the Origin of Decidual Stromal Cells in Eutherian Mammals. Mol Biol Evol 38:1060-1074. doi:10.1093/molbev/msaa274

Chen H, Song Y, Yang S, Fu J, Feng X, Huang W. 2017. YAP mediates human decidualization of the uterine endometrial stromal cells. Placenta 53:30-35. doi:10.1016/j.placenta.2017.03.013

Csapo A. 1956. Progesterone "block." Am J Anat 98:273-291. doi:10.1002/aja.1000980206 Csapo Al, Pinto-Dantas CA. 1965. The effect of progesterone on the human uterus. Proc Natl Acad Sci U S A 54:1069-1076.

Das SK. 2009. Cell cycle regulatory control for uterine stromal cell decidualization in implantation. Reprod Camb Engl 137:889-899. doi:10.1530/REP-08-0539

Deng W, Cha J, Yuan J, Haraguchi H, Bartos A, Leishman E, Viollet B, Bradshaw HB, Hirota Y, Dey SK. 2016. p53 coordinates decidual sestrin 2/AMPK/mTORC1 signaling to govern parturition timing. J Clin Invest 126:2941-2954. doi:10.1172/JCI87715

Deryabin P, Griukova A, Nikolsky N, Borodkina A. 2020. The link between endometrial stromal cell senescence and decidualization in female fertility: the art of balance. Cell Mol Life Sci CMLS 77:1357-1370. doi:10.1007/s00018-019-03374-0

Ecco G, Cassano M, Kauzlaric A, Duc J, Coluccio A, Offner S, Imbeault M, Rowe HM, Turelli P, Trono D. 2016. Transposable Elements and Their KRAB-ZFP Controllers Regulate Gene Expression in Adult Tissues. Dev Cell 36:611-623. 
doi:10.1016/j.devcel.2016.02.024

El-Deiry WS, Kern SE, Pietenpol JA, Kinzler KW, Vogelstein B. 1992. Definition of a consensus binding site for p53. Nat Genet 1:45-49. doi:10.1038/ng0492-45

Emera D, Romero R, Wagner G. 2012. The evolution of menstruation: A new model for genetic assimilation. BioEssays 34:26-35. doi:10.1002/bies.201100099

Emera D, Wagner GP. 2012. Transformation of a transposon into a derived prolactin promoter with function during human pregnancy. Proc Natl Acad Sci 109:11246-11251. doi:10.1073/pnas.1118566109

Erkenbrack EM, Maziarz JD, Griffith OW, Liang C, Chavan AR, Nnamani MC, Wagner GP. 2018. The mammalian decidual cell evolved from a cellular stress response. PLOS Biol 16:e2005594. doi:10.1371/journal.pbio.2005594

Feng J, Liu T, Qin B, Zhang Y, Liu XS. 2012. Identifying ChIP-seq enrichment using MACS. Nat Protoc 7:1728-1740. doi:10.1038/nprot.2012.101

Feschotte C. 2008. Transposable elements and the evolution of regulatory networks. Nat Rev Genet 9:397-405. doi:10.1038/nrg2337

Feschotte C, Gilbert C. 2012. Endogenous viruses: insights into viral evolution and impact on host biology. Nat Rev Genet 13:283-296. doi:10.1038/nrg3199

Finn CA. 1998. Menstruation: A Nonadaptive Consequence of Uterine Evolution. Q Rev Biol 73:163-173. doi:10.1086/420183

Fu T, Zheng H-T, Zhang H-Y, Chen Z-C, Li B, Yang Z-M. 2019. Oncostatin M expression in the mouse uterus during early pregnancy promotes embryo implantation and decidualization. FEBS Lett 593:2040-2050. doi:10.1002/1873-3468.13468

Gellersen B, Brosens IA, Brosens JJ. 2007. Decidualization of the Human Endometrium: Mechanisms, Functions, and Clinical Perspectives. Semin Reprod Med 25:445-453. doi:10.1055/s-2007-991042

Gellersen B, Brosens J. 2003. Cyclic AMP and progesterone receptor cross-talk in human endometrium: a decidualizing affair. J Endocrinol 178:357-372. doi:10.1677/joe.0.1780357

Gerlo S, Davis JR, Mager DL, Kooijman R. 2006. Prolactin in man: a tale of two promoters. Bioessays 28:1051-1055. doi:10.1002/bies.20468

Giudice LC. 2003. Elucidating endometrial function in the post-genomic era. Hum Reprod Update 9:223-235. doi:10.1093/humupd/dmg019

Hebenstreit D, Fang M, Gu M, Charoensawan V, van Oudenaarden A, Teichmann SA. 2011. 
RNA sequencing reveals two major classes of gene expression levels in metazoan cells. Mol Syst Biol 7:497. doi:10.1038/msb.2011.28

Imbeault M, Helleboid P-Y, Trono D. 2017. KRAB zinc-finger proteins contribute to the evolution of gene regulatory networks. Nature 543:550-554. doi:10.1038/nature21683

Jordan IK, Rogozin IB, Glazko GV, Koonin EV. 2003. Origin of a substantial fraction of human regulatory sequences from transposable elements. Trends Genet 19:68-72. doi:10.1016/S0168-9525(02)00006-9

Joswig A, Gabriel H-D, Kibschull M, Winterhager E. 2003. Apoptosis in uterine epithelium and decidua in response to implantation: evidence for two different pathways. Reprod Biol Endocrinol RBE 1:44. doi:10.1186/1477-7827-1-44

Kajihara T, Brosens JJ, Ishihara O. 2013. The role of FOXO1 in the decidual transformation of the endometrium and early pregnancy. Med Mol Morphol 46:61-68. doi:10.1007/s00795013-0018-z

Kawamura K, Kawamura N, Sato W, Fukuda J, Kumagai J, Tanaka T. 2009. Brain-derived neurotrophic factor promotes implantation and subsequent placental development by stimulating trophoblast cell growth and survival. Endocrinology 150:3774-3782. doi:10.1210/en.2009-0213

Kim D, Langmead B, Salzberg SL. 2015. HISAT: a fast spliced aligner with low memory requirements. Nat Methods 12:357-360. doi:10.1038/nmeth.3317

Kim D, Paggi JM, Park C, Bennett C, Salzberg SL. 2019. Graph-based genome alignment and genotyping with HISAT2 and HISAT-genotype. Nat Biotechnol 37:907-915. doi:10.1038/s41587-019-0201-4

Kim M, Park HJ, Seol JW, Jang JY, Cho Y-S, Kim KR, Choi Y, Lydon JP, Demayo FJ, Shibuya M, Ferrara N, Sung H-K, Nagy A, Alitalo K, Koh GY. 2013. VEGF-A regulated by progesterone governs uterine angiogenesis and vascular remodelling during pregnancy. EMBO Mol Med 5:1415-1430. doi:10.1002/emmm.201302618

Kim MR, Park DW, Lee JH, Choi DS, Hwang KJ, Ryu HS, Min CK. 2005. Progesteronedependent release of transforming growth factor-beta1 from epithelial cells enhances the endometrial decidualization by turning on the Smad signalling in stromal cells. Mol Hum Reprod 11:801-808. doi:10.1093/molehr/gah240

Kin K, Maziarz J, Chavan AR, Kamat M, Vasudevan S, Birt A, Emera D, Lynch VJ, Ott TL, Pavlicev M, Wagner GP. 2016. The Transcriptomic Evolution of Mammalian Pregnancy: Gene Expression Innovations in Endometrial Stromal Fibroblasts. Genome Biol Evol 


\section{8:2459-2473. doi:10.1093/gbe/evw168}

Kin K, Maziarz J, Wagner GP. 2014. Immunohistological Study of the Endometrial Stromal Fibroblasts in the Opossum, Monodelphis domestica: Evidence for Homology with Eutherian Stromal Fibroblasts1. Biol Reprod 90. doi:10.1095/biolreprod.113.115139

Kin K, Nnamani MC, Lynch VJ, Michaelides E, Wagner GP. 2015. Cell-type Phylogenetics and the Origin of Endometrial Stromal Cells. Cell Rep 10:1398-1409.

doi:10.1016/j.celrep.2015.01.062

Klonisch T, Wolf P, Hombach-Klonisch S, Vogt S, Kuechenhoff A, Tetens F, Fischer B. 2001. Epidermal Growth Factor-Like Ligands and erbB Genes in the Peri-Implantation Rabbit Uterus and Blastocyst1. Biol Reprod 64:1835-1844. doi:10.1095/biolreprod64.6.1835

Kunarso G, Chia N-Y, Jeyakani J, Hwang C, Lu X, Chan Y-S, Ng H-H, Bourque G. 2010.

Transposable elements have rewired the core regulatory network of human embryonic stem cells. Nat Genet 42:631-634. doi:10.1038/ng.600

Large MJ, Wetendorf M, Lanz RB, Hartig SM, Creighton CJ, Mancini MA, Kovanci E, Lee K-F, Threadgill DW, Lydon JP, Jeong J-W, DeMayo FJ. 2014. The epidermal growth factor receptor critically regulates endometrial function during early pregnancy. PLoS Genet 10:e1004451. doi:10.1371/journal.pgen.1004451

Lei W, Feng X-H, Deng W-B, Ni H, Zhang Z-R, Jia B, Yang X-L, Wang T-S, Liu J-L, Su R-W, Liang X-H, Qi Q-R, Yang Z-M. 2012. Progesterone and DNA damage encourage uterine cell proliferation and decidualization through up-regulating ribonucleotide reductase 2 expression during early pregnancy in mice. J Biol Chem 287:15174-15192. doi:10.1074/jbc.M111.308023

Liao Y, Wang J, Jaehnig EJ, Shi Z, Zhang B. 2019. WebGestalt 2019: gene set analysis toolkit with revamped Uls and APIs. Nucleic Acids Res 47:W199-W205. doi:10.1093/nar/gkz401

Logan PC, Ponnampalam AP, Rahnama F, Lobie PE, Mitchell MD. 2010. The effect of DNA methylation inhibitor 5-Aza-2'-deoxycytidine on human endometrial stromal cells. Hum Reprod Oxf Engl 25:2859-2869. doi:10.1093/humrep/deq238

Logan PC, Steiner M, Ponnampalam AP, Mitchell MD. 2012. Cell cycle regulation of human endometrial stromal cells during decidualization. Reprod Sci Thousand Oaks Calif 19:883-894. doi:10.1177/1933719112438447

Love MI, Huber W, Anders S. 2014. Moderated estimation of fold change and dispersion for RNA-seq data with DESeq2. Genome Biol 15:550. doi:10.1186/s13059-014-0550-8 
Lucas ES, Vrljicak P, Muter J, Diniz-da-Costa MM, Brighton PJ, Kong C-S, Lipecki J, Fishwick KJ, Odendaal J, Ewington LJ, Quenby S, Ott S, Brosens JJ. 2020. Recurrent pregnancy loss is associated with a pro-senescent decidual response during the peri-implantation window. Commun Biol 3:37. doi:10.1038/s42003-020-0763-1

Lynch VJ, Brayer K, Gellersen B, Wagner GP. 2009. HoxA-11 and FOXO1A Cooperate to Regulate Decidual Prolactin Expression: Towards Inferring the Core Transcriptional Regulators of Decidual Genes. PLOS ONE 4:e6845. doi:10.1371/journal.pone.0006845

Lynch VJ, Leclerc RD, May G, Wagner GP. 2011. Transposon-mediated rewiring of gene regulatory networks contributed to the evolution of pregnancy in mammals. Nat Genet 43:1154-1159. doi:10.1038/ng.917

Lynch VJ, Nnamani MC, Kapusta A, Brayer K, Plaza SL, Mazur EC, Emera D, Sheikh SZ, Grützner F, Bauersachs S, Graf A, Young SL, Lieb JD, DeMayo FJ, Feschotte C, Wagner GP. 2015. Ancient Transposable Elements Transformed the Uterine Regulatory Landscape and Transcriptome during the Evolution of Mammalian Pregnancy. Cell Rep 10:551-561. doi:10.1016/j.celrep.2014.12.052

Marinić M, Mika K, Chigurupati S, Lynch VJ. 2021. Evolutionary transcriptomics implicates HAND2 in the origins of implantation and regulation of gestation length. eLife 10:e61257. doi:10.7554/eLife.61257

Marinić M, Rana S, Lynch VJ. 2020. Derivation of endometrial gland organoids from term placenta. Placenta 101:75-79. doi:10.1016/j.placenta.2020.08.017

Matsui T, Leung D, Miyashita H, Maksakova IA, Miyachi H, Kimura H, Tachibana M, Lorincz MC, Shinkai Y. 2010. Proviral silencing in embryonic stem cells requires the histone methyltransferase ESET. Nature 464:927-931. doi:10.1038/nature08858

Mazur EC, Vasquez YM, Li X, Kommagani R, Jiang L, Chen R, Lanz RB, Kovanci E, Gibbons WE, DeMayo FJ. 2015. Progesterone Receptor Transcriptome and Cistrome in Decidualized Human Endometrial Stromal Cells. Endocrinology 156:2239-2253. doi:10.1210/en.2014-1566

Mess A, Carter AM. 2006. Evolutionary transformations of fetal membrane characters in Eutheria with special reference to Afrotheria. J Exp Zoolog B Mol Dev Evol 306B:140163. doi:10.1002/jez.b.21079

Mestre Citrinovitz AC, Strowitzki T, Germeyer A. 2019. Decreased Autophagy Impairs Decidualization of Human Endometrial Stromal Cells: A Role for ATG Proteins in Endometrial Physiology. Int J Mol Sci 20:E3066. doi:10.3390/ijms20123066 
Mika K, Marinić M, Singh M, Muter J, Brosens JJ, Lynch VJ. 2021a. Evolutionary transcriptomics implicates new genes and pathways in human pregnancy and adverse pregnancy outcomes. eLife 10:e69584. doi:10.7554/eLife.69584

Mika K, Whittington CM, McAllan BM, Lynch VJ. 2021b. Gene expression phylogenies and ancestral transcriptome reconstruction resolves major transitions in the origins of pregnancy. doi:10.1101/2021.09.27.461980

Ni N, Li Q. 2017. TGF $\beta$ superfamily signaling and uterine decidualization. Reprod Biol Endocrinol RBE 15:84. doi:10.1186/s12958-017-0303-0

Oksanen J, Blanchet FG, Friendly M, Kindt R, Legendre P, McGlinn D, Minchin PR, O'Hara RB, Simpson GL, Solymos P, Stevens MHH, Szoecs E, Wagner H. 2019. Vegan: community ecology package.

Pertea M, Kim D, Pertea GM, Leek JT, Salzberg SL. 2016. Transcript-level expression analysis of RNA-seq experiments with HISAT, StringTie and Ballgown. Nat Protoc 11:1650-1667. doi:10.1038/nprot.2016.095

Pertea M, Pertea GM, Antonescu CM, Chang T-C, Mendell JT, Salzberg SL. 2015. StringTie enables improved reconstruction of a transcriptome from RNA-seq reads. Nat Biotechnol 33:290-295. doi:10.1038/nbt.3122

Pijnenborg R, Vercruysse L, Brosens I. 2011a. Deep placentation. Best Pract Res Clin Obstet Gynaecol, Placental Bed \& Maternal - Fetal Disorders 25:273-285. doi:10.1016/j.bpobgyn.2010.10.009

Pijnenborg R, Vercruysse L, Carter AM. 2011b. Deep trophoblast invasion and spiral artery remodelling in the placental bed of the chimpanzee. Placenta 32:400-408. doi:10.1016/j.placenta.2011.02.009

Polak P, Domany E. 2006. Alu elements contain many binding sites for transcription factors and may play a role in regulation of developmental processes. BMC Genomics 7:133. doi:10.1186/1471-2164-7-133

Rawlings TM, Makwana K, Tryfonos M, Lucas ES. 2021. Organoids to model the endometrium: implantation and beyond. Reprod Fertil 2:R85-R101. doi:10.1530/RAF-21-0023

Rowe HM, Jakobsson J, Mesnard D, Rougemont J, Reynard S, Aktas T, Maillard PV, LayardLiesching H, Verp S, Marquis J, Spitz F, Constam DB, Trono D. 2010. KAP1 controls endogenous retroviruses in embryonic stem cells. Nature 463:237-240. doi:10.1038/nature08674

Rubel CA, Franco HL, Camper SA, Lanz RB, Jeong J-W, Lydon JP, DeMayo FJ. 2011. Gata2 Is 
a Master Regulator of Endometrial Function and Progesterone Signaling. Biol Reprod 85:179. doi:10.1093/biolreprod/85.s1.179

Rubel CA, Wu S-P, Lin L, Wang T, Lanz RB, Li X, Kommagani R, Franco HL, Camper SA, Tong Q, Jeong J-W, Lydon JP, DeMayo FJ. 2016. A Gata2-Dependent Transcription Network Regulates Uterine Progesterone Responsiveness and Endometrial Function. Cell Rep 17:1414-1425. doi:10.1016/j.celrep.2016.09.093

Sakabe NJ, Aneas I, Knoblauch N, Sobreira DR, Clark N, Paz C, Horth C, Ziffra R, Kaur H, Liu X, Anderson R, Morrison J, Cheung VC, Grotegut C, Reddy TE, Jacobsson B, Hallman M, Teramo K, Murtha A, Kessler J, Grobman W, Zhang G, Muglia LJ, Rana S, Lynch VJ, Crawford GE, Ober C, He X, Nóbrega MA. 2020. Transcriptome and regulatory maps of decidua-derived stromal cells inform gene discovery in preterm birth. Sci Adv 6:eabc8696. doi:10.1126/sciadv.abc8696

Salomonis N, Cotte N, Zambon AC, Pollard KS, Vranizan K, Doniger SW, Dolganov G, Conklin BR. 2005. Identifying genetic networks underlying myometrial transition to labor.

Genome Biol 6:R12. doi:10.1186/gb-2005-6-2-r12

Schwenke M, Knöfler M, Velicky P, Weimar CHE, Kruse M, Samalecos A, Wolf A, Macklon NS, Bamberger A-M, Gellersen B. 2013. Control of human endometrial stromal cell motility by PDGF-BB, HB-EGF and trophoblast-secreted factors. PloS One 8:e54336. doi:10.1371/journal.pone.0054336

Soares MJ, Varberg KM, Iqbal K. 2018. Hemochorial placentation: development, function, and adaptations†. Biol Reprod 99:196-211. doi:10.1093/biolre/ioy049

Stone JR, Wray GA. 2001. Rapid Evolution of cis-Regulatory Sequences via Local Point Mutations. Mol Biol Evol 18:1764-1770. doi:10.1093/oxfordjournals.molbev.a003964 Strassmann BI. 1996. The Evolution of Endometrial Cycles and Menstruation. Q Rev Biol 71:181-220. doi:10.1086/419369

Takano M, Lu Z, Goto T, Fusi L, Higham J, Francis J, Withey A, Hardt J, Cloke B, Stavropoulou AV, Ishihara O, Lam EW-F, Unterman TG, Brosens JJ, Kim JJ. 2007. Transcriptional cross talk between the forkhead transcription factor forkhead box $01 \mathrm{~A}$ and the progesterone receptor coordinates cell cycle regulation and differentiation in human endometrial stromal cells. Mol Endocrinol Baltim Md 21:2334-2349. doi:10.1210/me.2007-0058

Turco MY, Gardner L, Hughes J, Cindrova-Davies T, Gomez MJ, Farrell L, Hollinshead M, Marsh SGE, Brosens JJ, Critchley HO, Simons BD, Hemberger M, Koo B-K, Moffett A, 
Burton GJ. 2017. Long-term, hormone-responsive organoid cultures of human endometrium in a chemically defined medium. Nat Cell Biol 19:568-577. doi:10.1038/ncb3516

Wagner GP, Kin K, Lynch VJ. 2013. A model based criterion for gene expression calls using RNA-seq data. Theory Biosci 132:159-164. doi:10.1007/s12064-013-0178-3

Wang T, Zeng J, Lowe CB, Sellers RG, Salama SR, Yang M, Burgess SM, Brachmann RK, Haussler D. 2007. Species-specific endogenous retroviruses shape the transcriptional network of the human tumor suppressor protein p53. Proc Natl Acad Sci 104:1861318618. doi:10.1073/pnas.0703637104

Warrington NM, Beaumont RN, Horikoshi M, Day FR, Helgeland Ø, Laurin C, Bacelis J, Peng S, Hao K, Feenstra B, Wood AR, Mahajan A, Tyrrell J, Robertson NR, Rayner NW, Qiao Z, Moen G-H, Vaudel M, Marsit CJ, Chen J, Nodzenski M, Schnurr TM, Zafarmand MH, Bradfield JP, Grarup N, Kooijman MN, Li-Gao R, Geller F, Ahluwalia TS, Paternoster L, Rueedi R, Huikari V, Hottenga J-J, Lyytikäinen L-P, Cavadino A, Metrustry S, Cousminer DL, Wu Y, Thiering E, Wang CA, Have CT, Vilor-Tejedor N, Joshi PK, Painter JN, Ntalla I, Myhre R, Pitkänen N, van Leeuwen EM, Joro R, Lagou V, Richmond RC, Espinosa A, Barton SJ, Inskip HM, Holloway JW, Santa-Marina L, Estivill X, Ang W, Marsh JA, Reichetzeder C, Marullo L, Hocher B, Lunetta KL, Murabito JM, Relton CL, Kogevinas M, Chatzi L, Allard C, Bouchard L, Hivert M-F, Zhang G, Muglia LJ, Heikkinen J, Morgen CS, van Kampen AHC, van Schaik BDC, Mentch FD, Langenberg C, Luan J, Scott RA, Zhao JH, Hemani G, Ring SM, Bennett AJ, Gaulton KJ, Fernandez-Tajes J, van Zuydam NR, Medina-Gomez C, de Haan HG, Rosendaal FR, Kutalik Z, Marques-Vidal P, Das S, Willemsen G, Mbarek H, Müller-Nurasyid M, Standl M, Appel EVR, Fonvig CE, Trier C, van Beijsterveldt CEM, Murcia M, Bustamante M, Bonas-Guarch S, Hougaard DM, Mercader JM, Linneberg A, Schraut KE, Lind PA, Medland SE, Shields BM, Knight BA, Chai J-F, Panoutsopoulou K, Bartels M, Sánchez F, Stokholm J, Torrents D, Vinding RK, Willems SM, Atalay M, Chawes BL, Kovacs P, Prokopenko I, Tuke MA, Yaghootkar H, Ruth KS, Jones SE, Loh P-R, Murray A, Weedon MN, Tönjes A, Stumvoll M, Michaelsen KF, Eloranta A-M, Lakka TA, van Duijn CM, Kiess W, Körner A, Niinikoski H, Pahkala K, Raitakari OT, Jacobsson B, Zeggini E, Dedoussis GV, Teo Y-Y, Saw S-M, Montgomery GW, Campbell H, Wilson JF, Vrijkotte TGM, Vrijheid M, de Geus EJCN, Hayes MG, Kadarmideen HN, Holm J-C, Beilin LJ, Pennell CE, Heinrich J, Adair LS, Borja JB, Mohlke KL, Eriksson JG, Widén EE, Hattersley AT, Spector TD, Kähönen M, Viikari JS, 
Lehtimäki T, Boomsma DI, Sebert S, Vollenweider P, Sørensen TIA, Bisgaard H, Bønnelykke K, Murray JC, Melbye M, Nohr EA, Mook-Kanamori DO, Rivadeneira F, Hofman A, Felix JF, Jaddoe VWV, Hansen T, Pisinger C, Vaag AA, Pedersen O, Uitterlinden AG, Järvelin M-R, Power C, Hyppönen E, Scholtens DM, Lowe WL, Davey Smith G, Timpson NJ, Morris AP, Wareham NJ, Hakonarson H, Grant SFA, Frayling TM, Lawlor DA, Njølstad PR, Johansson S, Ong KK, McCarthy MI, Perry JRB, Evans DM, Freathy RM. 2019. Maternal and fetal genetic effects on birth weight and their relevance to cardio-metabolic risk factors. Nat Genet 51:804-814. doi:10.1038/s41588-019-0403-1 Wheeler TJ, Clements J, Eddy SR, Hubley R, Jones TA, Jurka J, Smit AFA, Finn RD. 2013. Dfam: a database of repetitive DNA based on profile hidden Markov models. Nucleic Acids Res 41:D70-D82. doi:10.1093/nar/gks1265

Wray GA. 2007. The evolutionary significance of cis-regulatory mutations. Nat Rev Genet 8:206-216. doi:10.1038/nrg2063

Wu L, Stadtmauer DJ, Maziarz J, Wagner G. 2020. Decidual cell differentiation is evolutionarily derived from fibroblast activation. doi:10.1101/2020.12.18.423527

Yu H-F, Duan C-C, Yang Z-Q, Wang Y-S, Yue Z-P, Guo B. 2019. HB-EGF Ameliorates Oxidative Stress-Mediated Uterine Decidualization Damage. Oxid Med Cell Longev 2019:6170936. doi:10.1155/2019/6170936

Zhang Q, Yan J. 2016. Update of Wnt signaling in implantation and decidualization. Reprod Med Biol 15:95-105. doi:10.1007/s12522-015-0226-4

Zhang Y, Liu T, Meyer CA, Eeckhoute J, Johnson DS, Bernstein BE, Nusbaum C, Myers RM, Brown M, Li W, Liu XS. 2008. Model-based Analysis of ChIP-Seq (MACS). Genome Biol 9:R137. doi:10.1186/gb-2008-9-9-r137 
Table 1. Pathways in which genes regulated by primate-specific eTE-derived PGR bindingsites are enriched. E, enrichment ratio. P, hypergeometric P-value. FDR, Benjamini-Hochberg false discovery rate. Reference, reference for role of pathway in decidualization.

\begin{tabular}{|c|c|c|c|c|c|}
\hline Rank & Pathway & $\mathbf{E}$ & $\mathbf{P}$ & FDR & Reference \\
\hline 2 & VEGFA-VEGFR2 Signaling Pathway & 2.60 & $2 \mathrm{E}-8$ & $2.75 \mathrm{E}-5$ & (Kim et al., 2013) \\
\hline 6 & Insulin signaling pathway & 3.79 & $6 \mathrm{E}-7$ & $2.72 \mathrm{E}-4$ & $\begin{array}{l}\text { (Kawamura et al. } \\
\text { 2009) }\end{array}$ \\
\hline 13 & TGF-beta Signaling Pathway & 3.52 & $6 \mathrm{E}-6$ & $1.38 \mathrm{E}-3$ & (Kim et al., 2005) \\
\hline 17 & ErbB Signaling Pathway & 3.91 & $3 E-5$ & $4.28 \mathrm{E}-3$ & $\begin{array}{l}\text { (Klonisch et al., } \\
\text { 2001) }\end{array}$ \\
\hline 26 & Hippo signaling pathway & 3.02 & $5 \mathrm{E}-5$ & $5.32 \mathrm{E}-3$ & $\begin{array}{l}\text { (Chen et al., } \\
\text { 2017) }\end{array}$ \\
\hline 27 & PDGF signaling pathway & 3.28 & $5 E-5$ & $5.41 \mathrm{E}-3$ & $\begin{array}{l}\text { (Schwenke et al., } \\
\text { 2013) }\end{array}$ \\
\hline 35 & FoxO signaling pathway & 3.11 & $9 \mathrm{E}-5$ & 7.84E-3 & $\begin{array}{l}\text { (Kajihara et al., } \\
\text { 2013) }\end{array}$ \\
\hline 37 & Mitophagy & 4.21 & $1 \mathrm{E}-4$ & 8.71E-3 & $\begin{array}{l}\text { (Mestre } \\
\text { Citrinovitz et al., } \\
\text { 2019) }\end{array}$ \\
\hline 38 & Oncostatin M Signaling Pathway & 4.21 & $1 \mathrm{E}-4$ & 8.71E-3 & (Fu et al., 2019) \\
\hline 40 & TGF-beta Receptor Signaling & 4.56 & $1 \mathrm{E}-4$ & $9.63 E-3$ & (Ni and Li, 2017) \\
\hline 52 & BDNF signaling pathway & 2.85 & $3 \mathrm{E}-4$ & $1.40 \mathrm{E}-2$ & $\begin{array}{l}\text { (Kawamura et al. } \\
\text { 2009) }\end{array}$ \\
\hline 54 & EGF/EGFR Signaling Pathway & 2.70 & $3 \mathrm{E}-4$ & $1.54 \mathrm{E}-2$ & $\begin{array}{l}\text { (Large et al., } \\
\text { 2014) }\end{array}$ \\
\hline 55 & Wnt signaling pathway & 2.81 & $3 \mathrm{E}-4$ & $1.54 \mathrm{E}-2$ & $\begin{array}{l}\text { (Zhang and Yan, } \\
\text { 2016) }\end{array}$ \\
\hline 65 & Prolactin Signaling Pathway & 3.60 & $4 \mathrm{E}-4$ & $1.90 \mathrm{E}-2$ & (Bao et al., 2007) \\
\hline 74 & Myometrial Relaxation and Contraction Pathways & 2.63 & $6 \mathrm{E}-4$ & 2.32E-2 & $\begin{array}{l}\text { (Salomonis et al., } \\
\text { 2005) }\end{array}$ \\
\hline
\end{tabular}


Table 2. Pathways related to senescence and the cell-cycle in which genes regulated by primate-specific eTE-derived PGR binding-sites are enriched. E, enrichment ratio. $P$, hypergeometric P-value. FDR, Benjamini-Hochberg false discovery rate. Reference, reference for role of pathway in decidualization.

\begin{tabular}{|c|c|c|c|c|c|}
\hline Rank & Pathway & $\mathbf{E}$ & $\mathbf{P}$ & FDR & Reference \\
\hline 11 & Cellular senescence & 3.25 & $6 \mathrm{E}-6$ & $1.38 \mathrm{E}-3$ & $\begin{array}{l}\text { (Lucas et al., } \\
2020)\end{array}$ \\
\hline 14 & $\begin{array}{l}\text { DNA Damage } \\
\text { Response (only ATM } \\
\text { dependent) }\end{array}$ & 3.73 & $1 \mathrm{E}-5$ & 2.23E-3 & (Lei et al., 2012) \\
\hline 19 & G2/M Transition & 2.82 & $3 \mathrm{E}-5$ & 4.37E-3 & $\begin{array}{l}\text { (Logan et al., } \\
\text { 2012) }\end{array}$ \\
\hline 20 & Mitotic G2-G2/M phases & 2.79 & $3 \mathrm{E}-5$ & 4.70E-3 & $\begin{array}{l}\text { (Logan et al., } \\
\text { 2012) }\end{array}$ \\
\hline 41 & $\begin{array}{l}\text { Apoptosis signaling } \\
\text { pathway }\end{array}$ & 3.29 & $2 \mathrm{E}-4$ & $1.08 \mathrm{E}-2$ & $\begin{array}{l}\text { (Joswig et al., } \\
\text { 2003) }\end{array}$ \\
\hline 42 & Oxidative Stress & 5.80 & $2 \mathrm{E}-4$ & $1.08 \mathrm{E}-2$ & (Yu et al., 2019) \\
\hline 59 & Mitotic G1-G1/S phases & 2.75 & $4 \mathrm{E}-4$ & 1.79E-2 & $\begin{array}{l}\text { (Logan et al., } \\
\text { 2012) }\end{array}$ \\
\hline 66 & Cell Cycle & 2.96 & $4 \mathrm{E}-4$ & 1.92E-2 & (Das, 2009) \\
\hline 67 & $\begin{array}{l}\text { Senescence and } \\
\text { Autophagy in Cancer }\end{array}$ & 3.12 & $4 \mathrm{E}-4$ & $1.92 \mathrm{E}-2$ & $\begin{array}{l}\text { (Deryabin et al., } \\
\text { 2020) }\end{array}$ \\
\hline 75 & Cell cycle & 2.87 & $6 \mathrm{E}-4$ & 2.32E-2 & (Das, 2009) \\
\hline 91 & $\begin{array}{l}\text { Cyclin D associated } \\
\text { events in G1 }\end{array}$ & 4.35 & $1 \mathrm{E}-3$ & 3.09E-2 & $\begin{array}{l}\text { (Logan et al., } \\
\text { 2012) }\end{array}$ \\
\hline 92 & G1 Phase & 4.35 & $1 \mathrm{E}-3$ & 3.09E-2 & $\begin{array}{l}\text { (Logan et al., } \\
\text { 2012) }\end{array}$ \\
\hline 99 & p53 signaling pathway & 3.42 & $1 \mathrm{E}-3$ & $3.45 \mathrm{E}-2$ & $\begin{array}{l}\text { (Deng et al., } \\
\text { 2016) }\end{array}$ \\
\hline
\end{tabular}



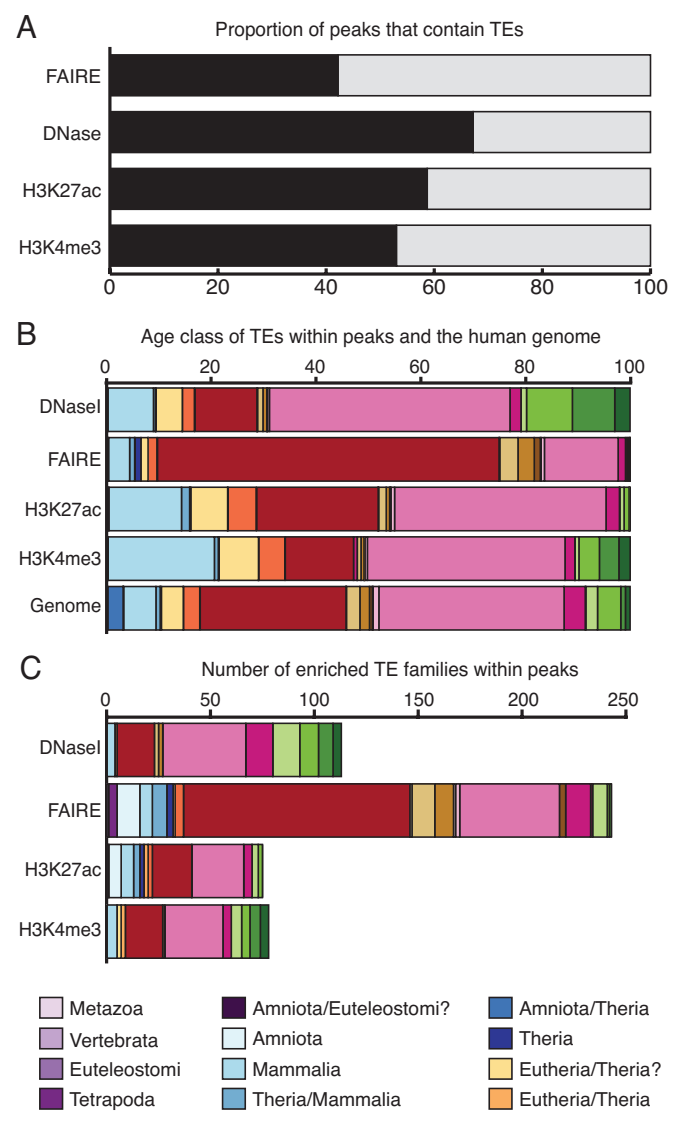
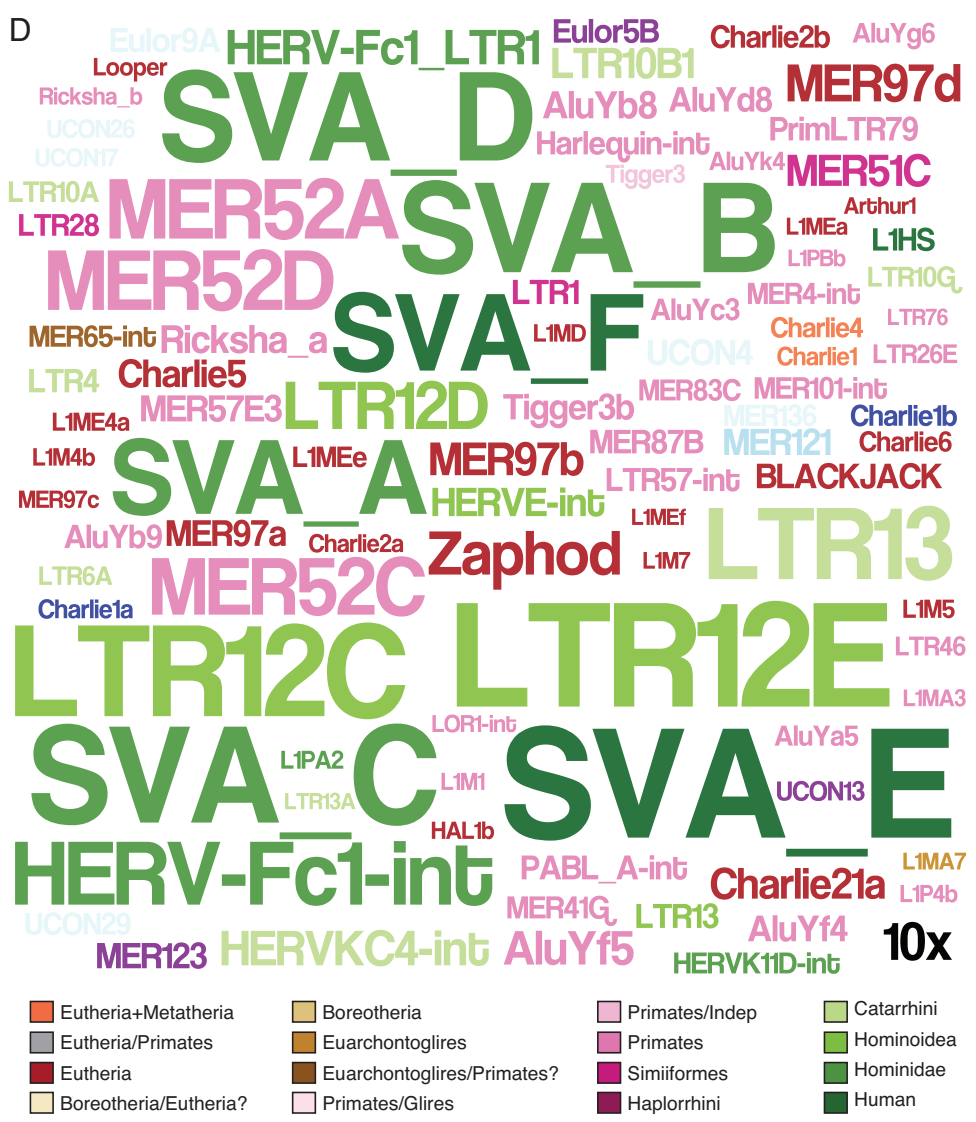

Figure 1. Transposable elements are major contributors to regulatory elements in endometrial stromal cells.

(A) Proportion of DNasel-Seq, FAIRE-Seq, H3K27ac ChIP-Seq, and H3K4me3 ChIP-Seq peaks that contain transposable elements (black) or no annotated transposable elements (gray).

(B) Proportion of transposable elements of different ages (color coded by lineage specificity) within DNasel-seq, FAIRE-seq, H3K27ac ChIP-seq, and H3K4me3 ChIP-Seq peaks and the human genome.

(C) Number of transposable element families enriched within DNasel-seq, FAIRE-seq, H3K27ac ChIP-seq, and H3K4me3 ChIP-Seq peaks compared to the human genome.

(D) WordCloud of the 100 most enriched transposable elements within DNasel-seq, FAIREseq, H3K27ac ChIP-seq, and H3K4me3 ChIP-Seq peaks. The size of the transposable element's name corresponds to its enrichment (see inset 10-fold scale). Legend indicates the lineage-specificity (age) colored coding of transposable elements. 
Figure 1 - Source data 1. Transposable elements enriched in DNasel-Seq peaks in human DSCs.

Figure 1 - Source data 2. Transposable elements enriched in FAIRE-Seq peaks in human DSCs.

Figure 1 - Source data 3. Transposable elements enriched in H3K4me3 ChIP-Seq peaks in human DSCs.

Figure 1 - Source data 4. Transposable elements enriched in H3K27ac ChIP-Seq peaks in human DSCs.

Figure 1 - Source data 5. Summary enrichment data for the 427 eTEs. 

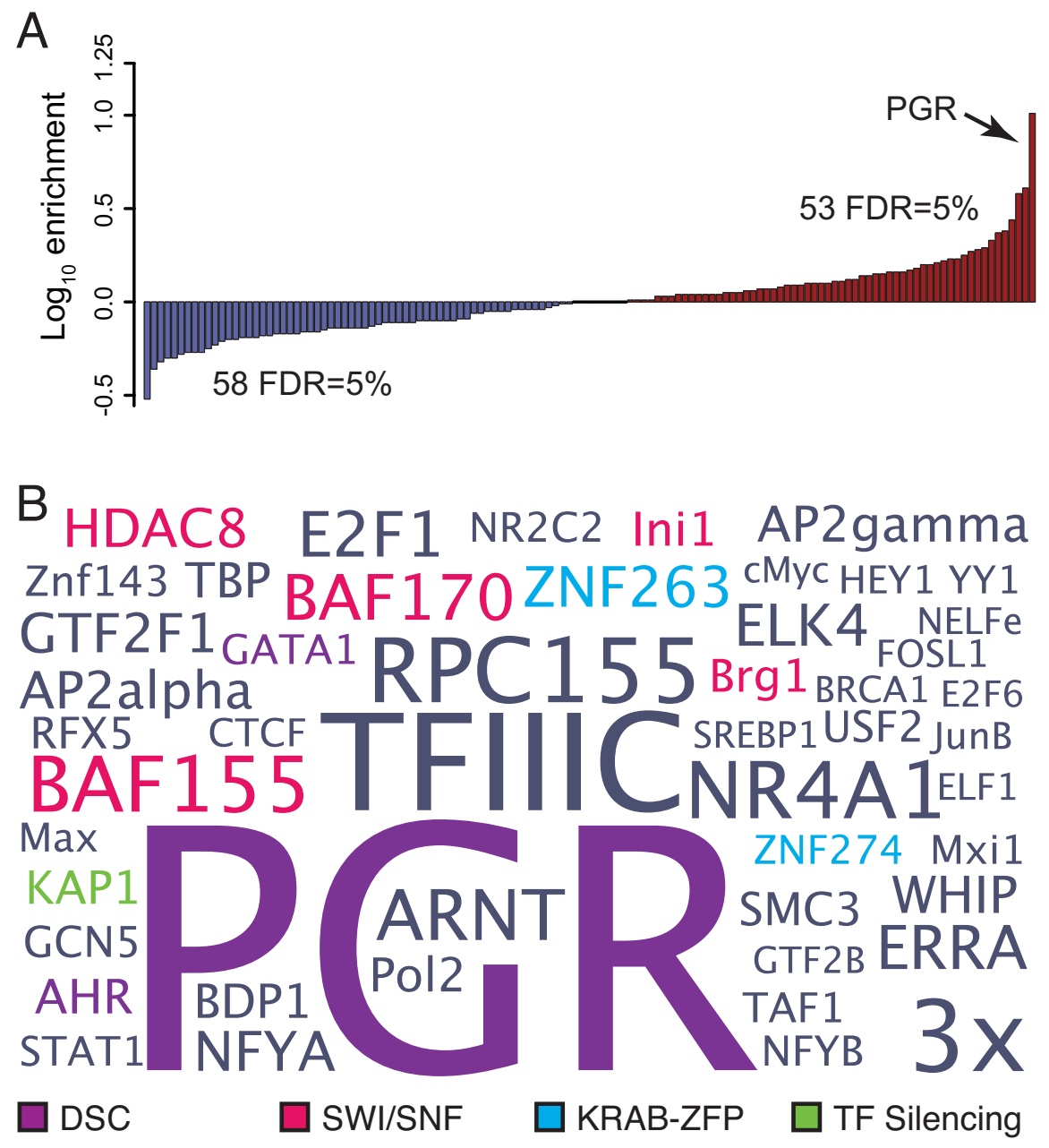

Figure 2. Transposable elements are enriched in binding sites for transcription factors that mediate hormone responsiveness and endometrial cell-type identity.

(A) Distribution of enriched (red) and depleted (blue) transcription factor binding sites in transposable element derived segments of FAIRE-seq, DNasel-seq, H3K27ac ChIP-seq, and H3K4me3 ChIP-Seq peaks relative to ChIP-Seq peaks with no transposable element overlap. 53 and 58 transcription factor binding sites were significantly enriched and depleted, respectively, at FDR $=0.05 \%$.

(B) WordCloud of transcription factor binding site enrichment in transposable elements. Colors indicate transcription factors that mediate hormone responses (purple), remodel chromatin (pink), KRAB-ZFPs (blue), or involved in TE silencing (green). Data shown for $\geq 3$-fold enriched transcription factors at FDR $=0.05 \%$.

Figure 2 - Source data 1. Transcription factors enriched in regulatory eTEs. 
A
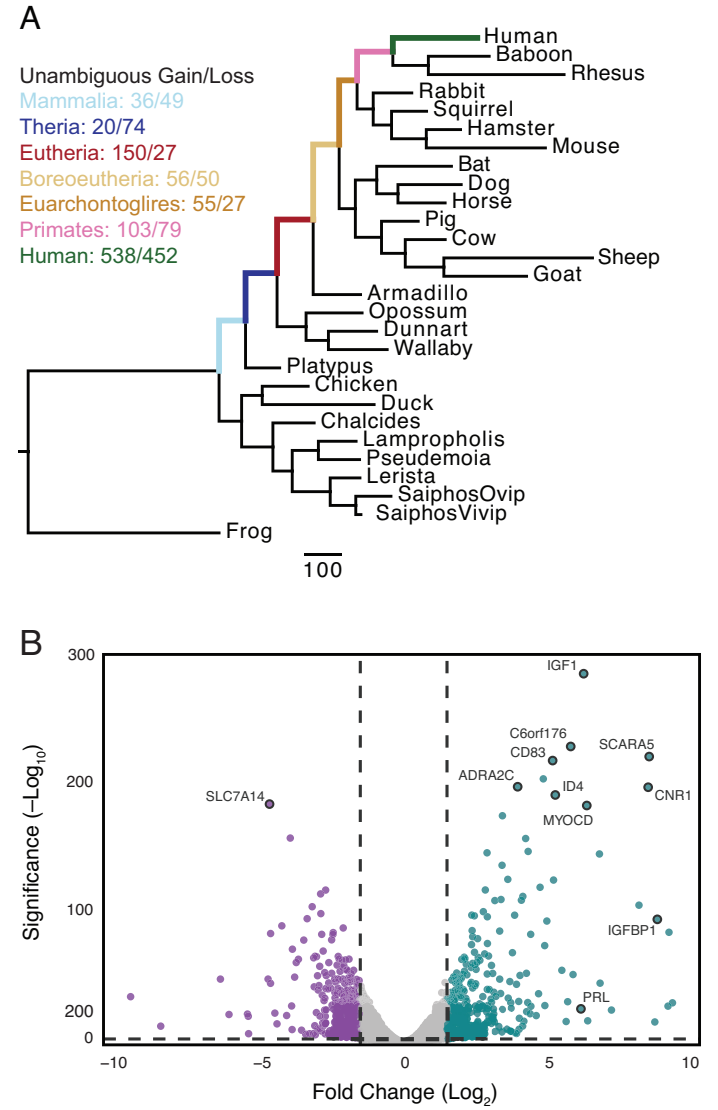

C

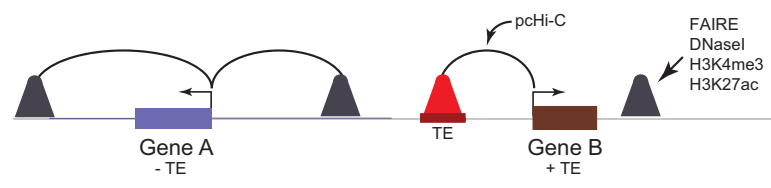

D

$\log _{2}$ Fold Change Expression (DSC/ESF)

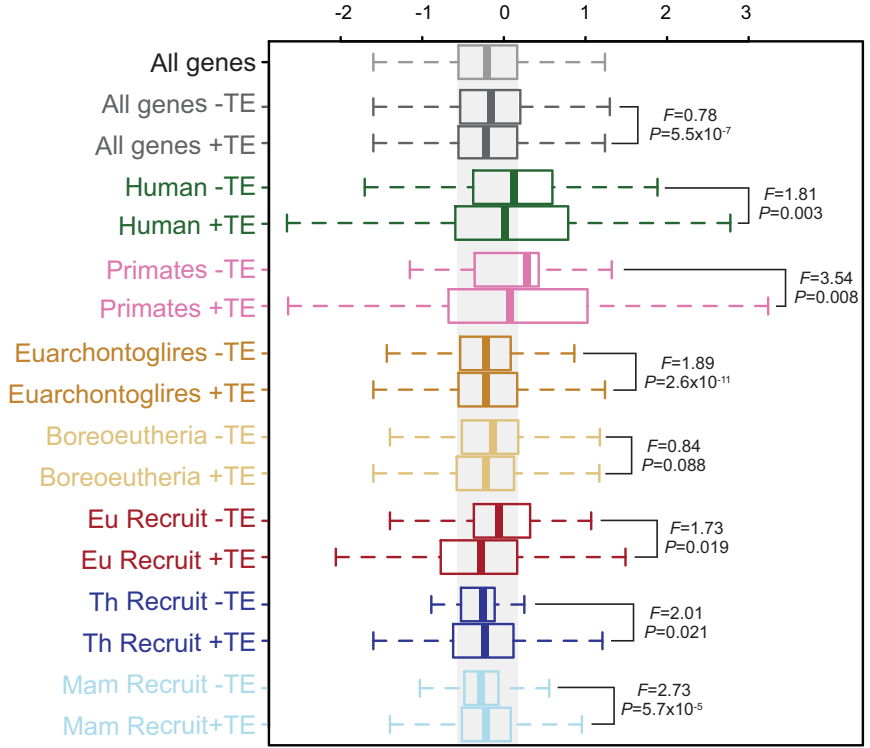

Figure 3. Genes associated with TE-derived regulatory elements are more strongly differentially regulated during decidualization than genes without TE-derived regulatory elements.

(A) Parsimony reconstruction of gene expression gains and losses in the endometrium of amniotes. Numbers above branches indicate the average number of genes that gained and lost endometrial expression in that stem-lineage as inferred by parsimony. Branch lengths are drawn proportional to gene expression gain and loss events for all lineages.

(B) Volcano chart showing genes differentially expressed between ESFs and DSCs. Upregulated genes are shown in blue, downregulated genes are shown in purple. Exemplar differentially expressed genes are indicated.

(C) Cartoon of the pcHiC data to associate regulatory elements with nearby genes.

(D) Recruited and ancestrally expressed genes associated with ancient mammalian TEderived regulatory elements $(+)$ are more strongly differentially regulated upon cAMP/MPA-induced decidualization than recruited or anciently expressed genes without TE-derived regulatory elements (-). $\mathrm{F}$ is the ratio of variances from a two-sample F-test. 
bioRxiv preprint doi: https://doi.org/10.1101/2021.10.25.465769; this version posted October 26, 2021. The copyright holder for this preprint (which was not certified by peer review) is the author/funder, who has granted bioRxiv a license to display the preprint in perpetuity. It is made available under aCC-BY 4.0 International license.

Figure 3 - Source data 1. Parsimony reconstruction of genes that unambiguously gained and lost endometrial expression.

Figure 3 - Source data 2. Gene expression changes induced by decidualization (from dataset GSE94036).

Figure 3 - Source data 3. pcHiC data from human DSCs (from dataset SDY1626). 

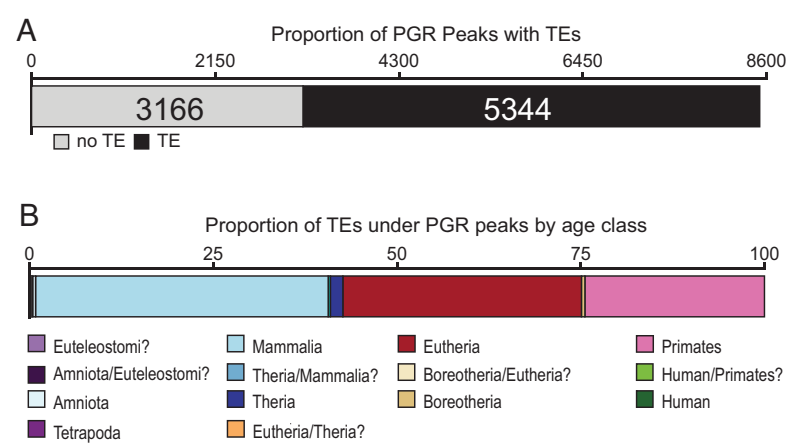

c Tigger2b_Pri-" MER41D

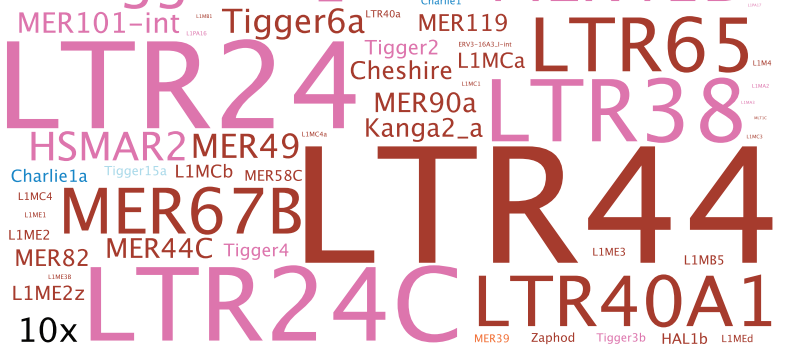

$\mathrm{F}$

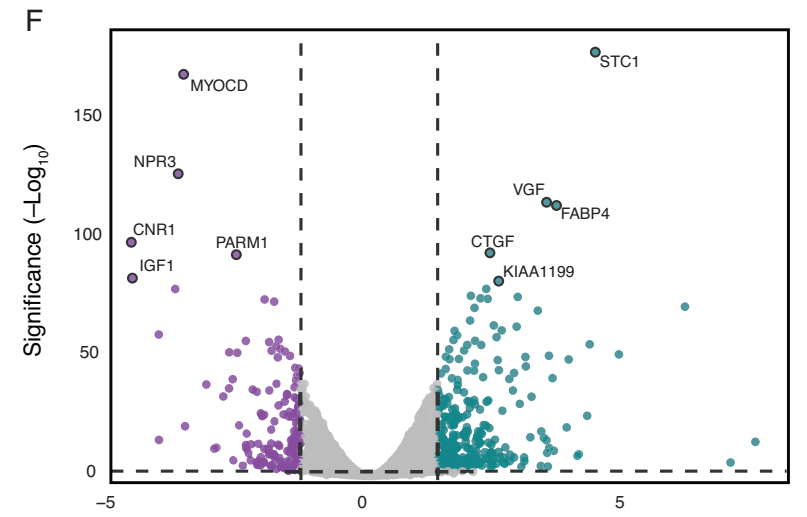

Log $_{2}$ Fold Change (siPGR/siCTL)
D
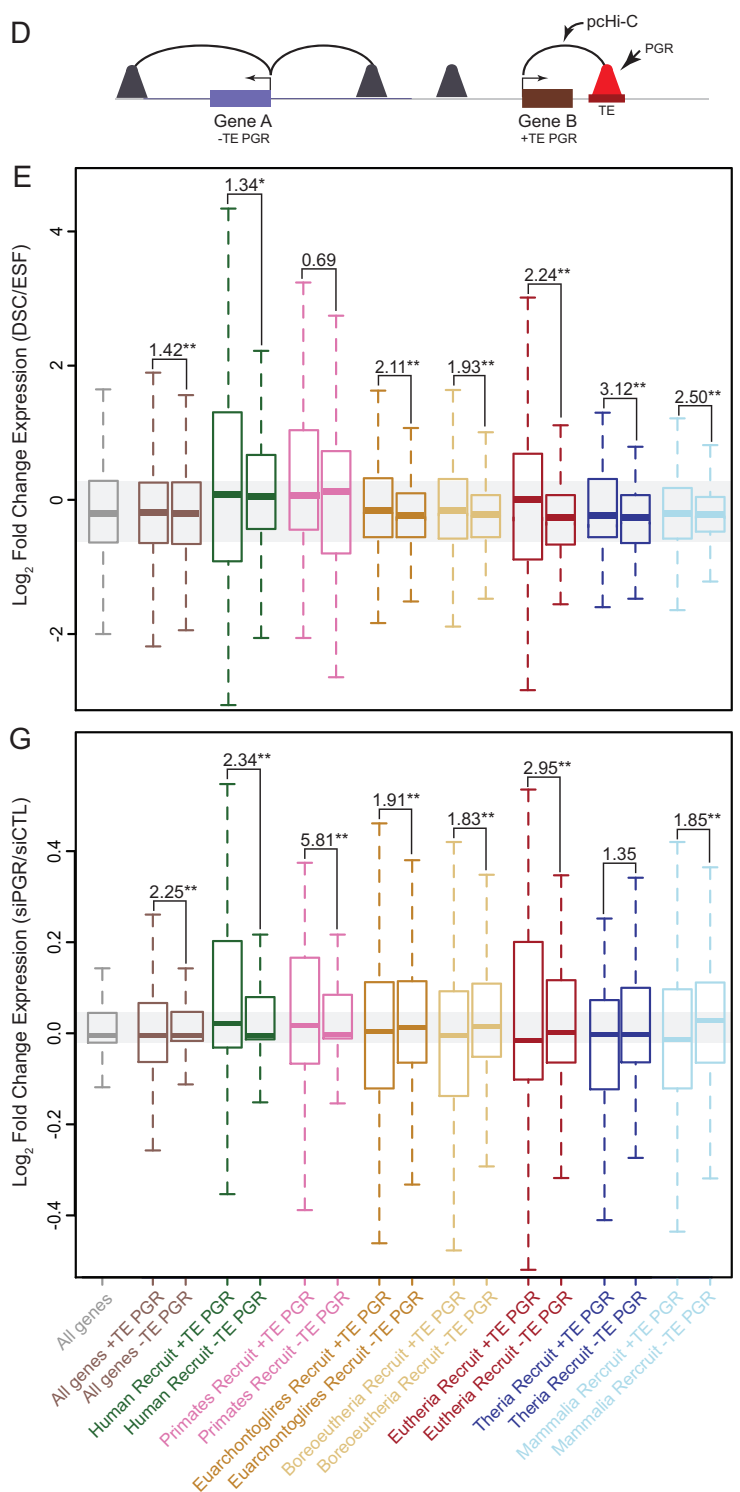

Figure 4. Lineage specific transposable elements remodeled progesterone receptor binding site architecture across the genome.

(A) The number of PGR ChIP-Seq peaks that contain transposable elements in human decidual stromal cells.

(B) Proportion of transposable elements in PGR ChIP-Seq peaks by age class.

(C) WordCloud of TEs enriched in PGR ChIP-Seq peaks. Colors indicate age class. Inset scale (10x) shows 10-fold enrichment.

(D) Cartoon of the pcHiC data to PGR binding sites with nearby genes.

(E) Ancestrally expressed and recruited genes associated with TE-derived PGR binding sites (+ PGR) are more strongly differentially regulated by CAMP/MPA than genes without TEderived PGR binding sites (-PGR). 
(F) Volcano chart showing genes differentially expressed between DSCs treated with control non-targeting siRNA and PGR-specific siRNA. Upregulated genes are shown in blue, downregulated genes are shown in purple. Exemplar differentially expressed genes are indicated.

(G) Ancestrally expressed and recruited genes associated with TE-derived PGR binding sites (+ PGR) are more strongly dysregulated by PGR knockdown in human DSCs than genes not associated with ancient mammalian TE-derived PGR biding sites (- PGR). $F$ is the ratio of variances from a two-sample F-test. Genes are grouped according to when they evolved endometrial expression. ${ }^{*}=\mathrm{P}<0.01,{ }^{* *}=\mathrm{P}<1.0 \times 10-5$.

Figure 4 - Source data 1. Transposable elements enriched in PGR ChIP-Seq peaks in human DSCs.

Figure 4 - Source data 2. Gene expression changes induced by siRNA mediated PGR knockdown (from dataset GSE94036). 
A
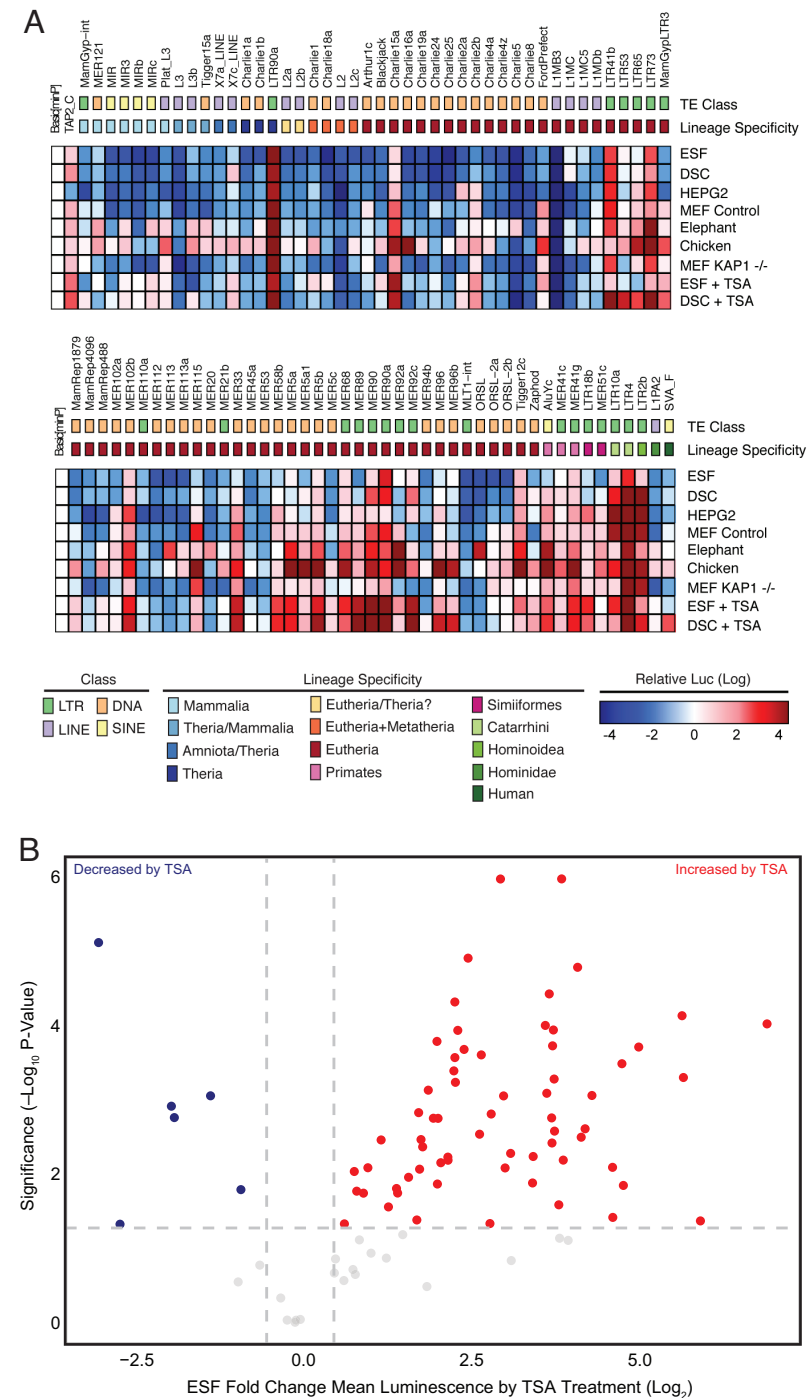
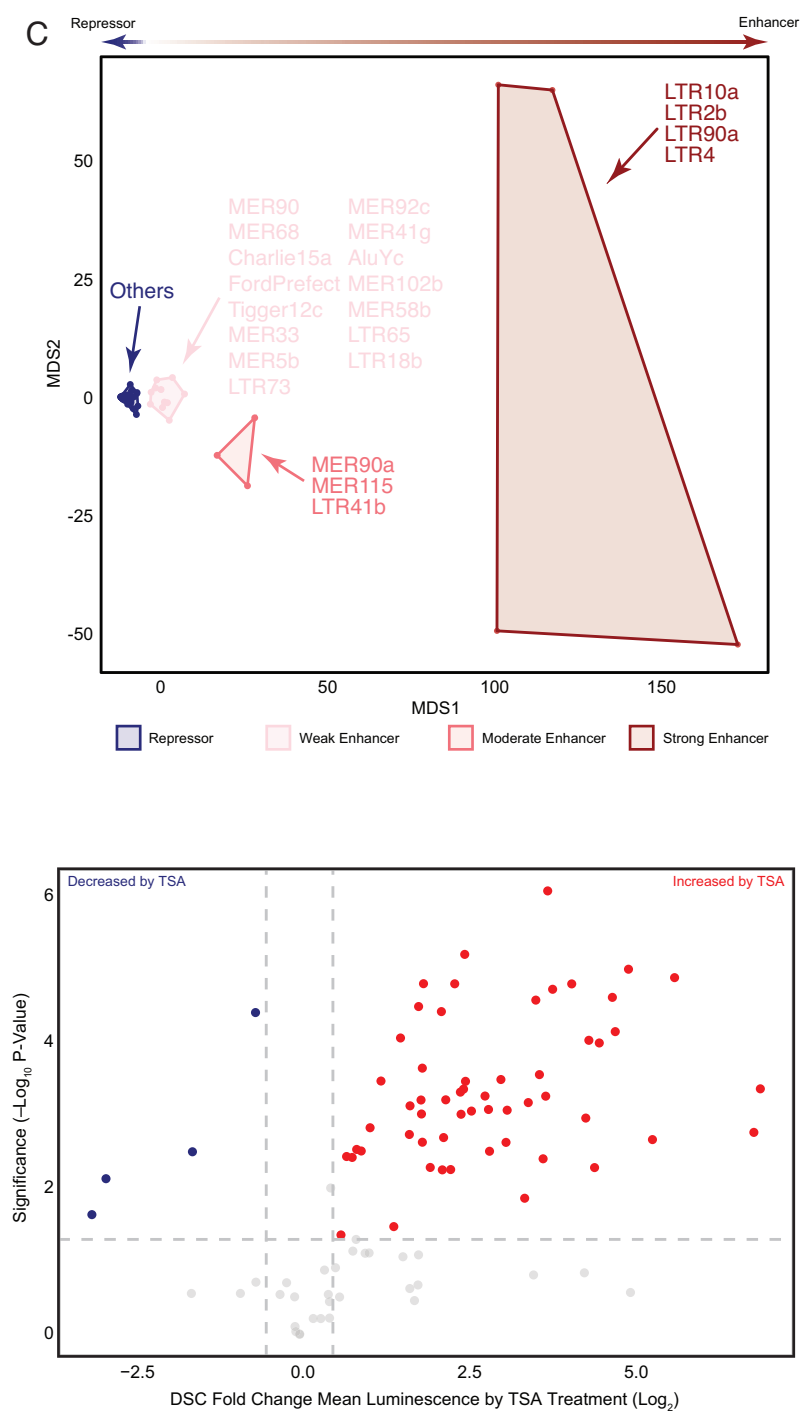

Figure 5. Consensus TEs are repressors with hidden enhancer potential.

(A) Regulatory ability of consensus TEs was assessed using a dual luciferase reporter vector. Each box represents the mean luminescence values $(\mathrm{log})$ of 4-6 replicate reporter assays. Basic[minP], empty reporter vector reference. TAP2_C is a known progesterone responsive enhancer ${ }^{44}$. The 89 TE constructs are sorted in order of decreasing age inferred by lineage specificity. Red indicates enhancer function and blue indicates repressor function (see inset color scale). ESF - Endometrial Stromal Fibroblasts, DSC Decidual Stromal Cells, HEPG2 - Human Liver Cancer, MEF Control - Mouse Embryonic Fibroblast, MEF KAP1\% - Mouse KAP1 knockout Embryonic Fibroblast, Elephant Elephant Dermal Fibroblast, Chicken - Chicken Embryonic Fibroblast, +TSA - Trichostatin A added to media.

(B) Volcano Plot ESF vs ESF treated with TSA and DSC vs DSC treated with TSA 
bioRxiv preprint doi: https://doi.org/10.1101/2021.10.25.465769; this version posted October 26, 2021. The copyright holder for this preprint (which was not certified by peer review) is the author/funder, who has granted bioRxiv a license to display the preprint in perpetuity. It is made available under aCC-BY 4.0 International license.

(C) Multidimensional scaling plot (MDS) of consensus TEs based on mean luminescence values (log) and grouped by K-means clustering $(\mathrm{k}=4)$. K-means clustering groups TEs into four categories corresponding to TEs with strong/moderate/weak enhancer or repressor functions. 


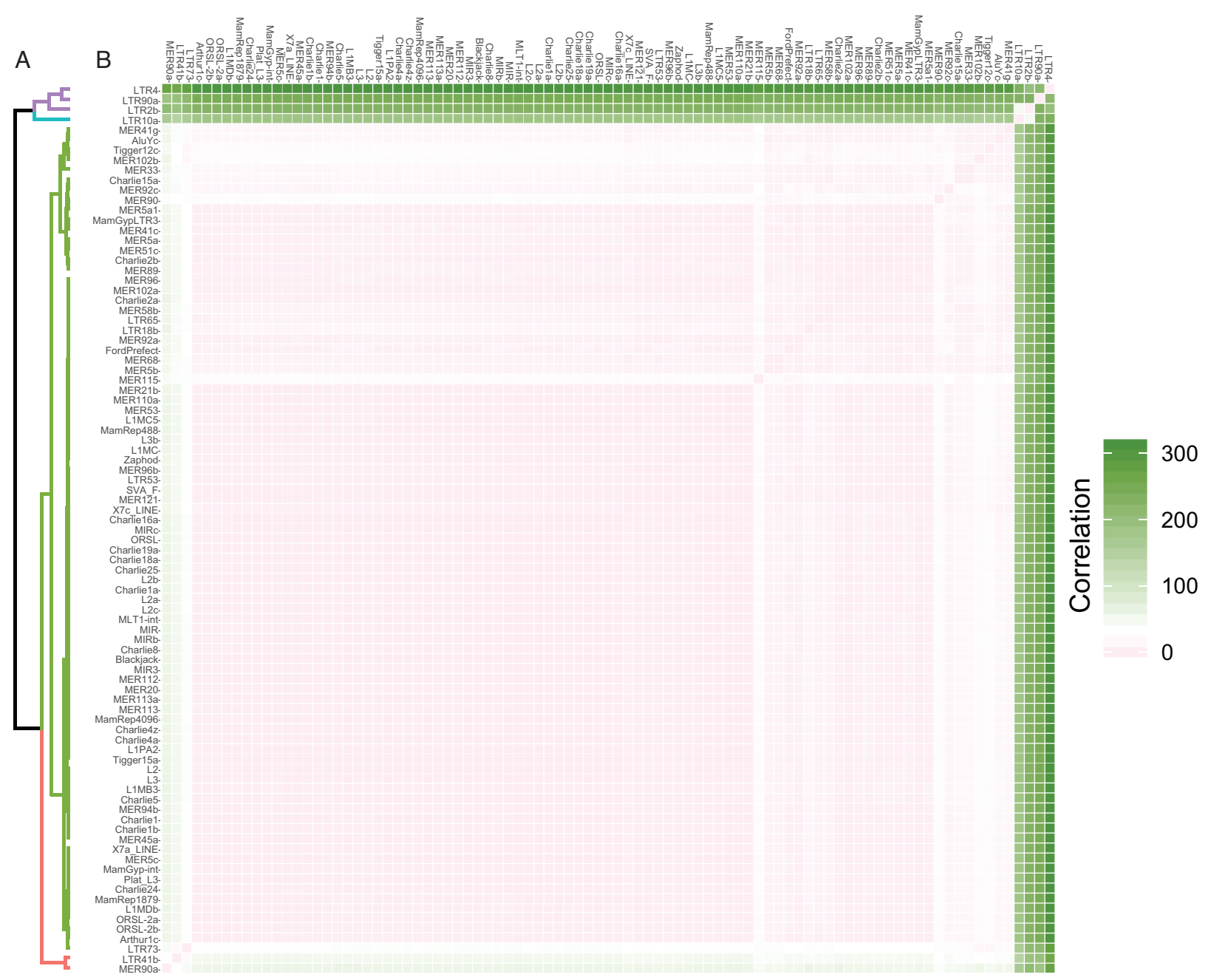

Figure 5 - figure supplement 1. Hierarchical clustering of consensus TEs.

(A) Hierarchical clustering (Manhattan distances) dendogram of consensus TEs based on mean luminescence values (log) and colored by $\mathrm{K}$-means clustering ( $k=4)$. K-means clustering groups TEs into four categories corresponding to TEs with strong/moderate/weak enhancer or repressor functions.

(B) Correlation matrix heatmap. 

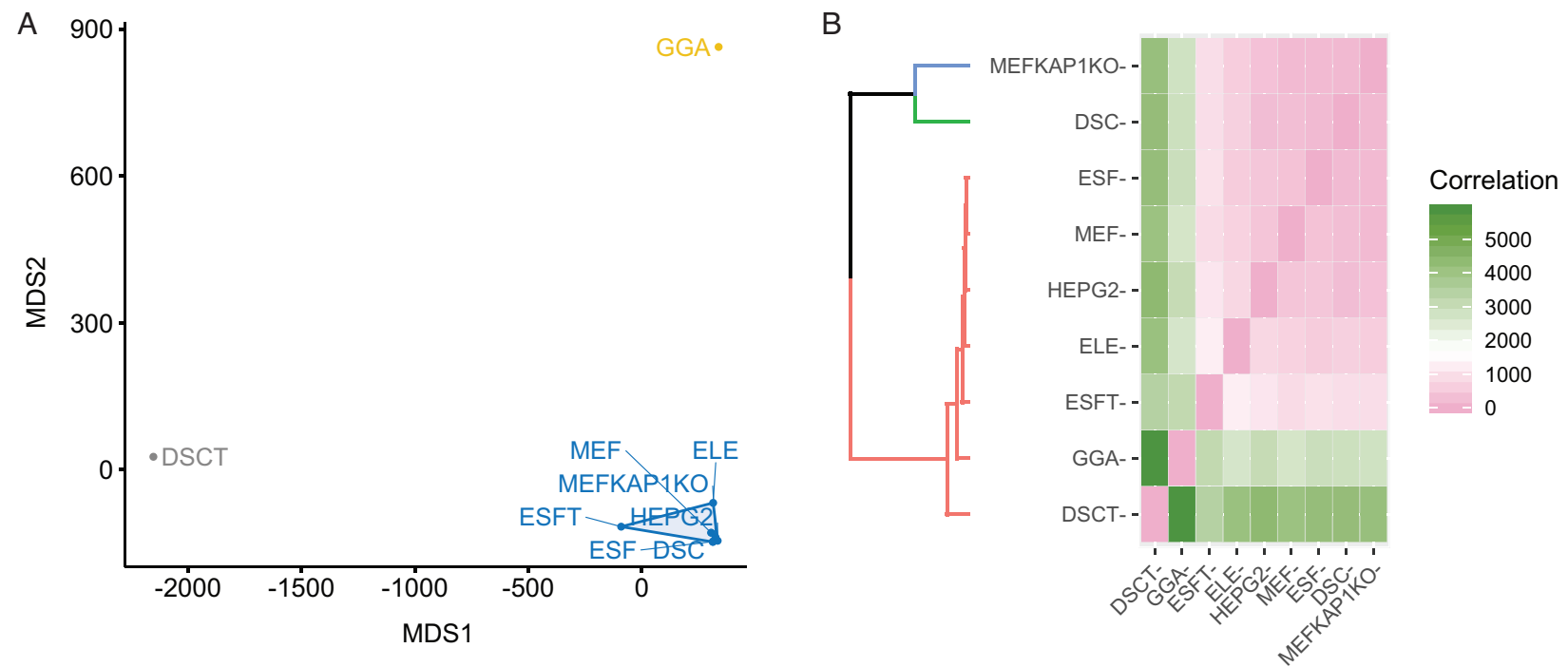

Figure 5 - figure supplement 2. MDS and hierarchical clustering of cell types based on conTE luciferase results.

(A) Multidimensional scaling plot (MDS) of cell-types based on consensus TE mean luminescence values (log) and grouped by K-means clustering ( $\mathrm{k}=3)$.

(B) Hierarchical clustering (Manhattan distances) dendogram and correlation matrix heatmap of cell-types based on consensus TE mean luminescence values (log) colored by Kmeans clustering $(k=3)$.

Figure 5 - Source data 1. Consensus TE sequences.

Figure 5 - Source data 2. Dual luciferase assay results for six replicates in all cell-types. 